\title{
The Pricing of Non-Price Terms in Sovereign Bonds: The Case of the Greek Guarantees
}

\author{
Stephen J. Choi ${ }^{1}$ and Mitu Gulati ${ }^{2 *}$ \\ ${ }^{1}$ New York University School of Law, New York, USA \\ ${ }^{2}$ Duke University School of Law, USA
}

\begin{abstract}
In March 2012, Greece conducted one of the biggest and most brutal sovereign debt restructurings ever, asking holders of Greek government bonds to take net present value haircuts of near 80 percent. Greece forced acquiescence to its terms from a large number of its bonds by using a variety of legal strong-arm tactics. With the vast majority of Greek bonds, the tactics worked. There were, however, thirty-six bonds guaranteed by the Greek state, which, because of the weakness of the underlying companies, were effectively obligations of the Greek state. Yet, on these thirtysix bonds, even though Greece desperately needed every euro of respite it could get, no restructuring was even attempted. Why not? The answer we received was that the guarantees escaped the restructuring because their contractual provisions made them much harder to restructure than the ordinary Greek government bonds. Assuming this contract-based claim to be true, the foregoing, in combination with the Euro area crisis of 2010-2014 throws up an opportunity to test the extent to which markets price legal differences in bond contract terms. We report evidence that the markets did price in at least some of the advantage that guaranteed bonds had over ordinary sovereign bonds in the months immediately prior to the March 2012 restructuring.
\end{abstract}

${ }^{*}$ Thanks to Franklin Allen, Michael Bradley, Bernard Black, Bill Bratton, Lee Buchheit, Elena Carletti, Joseph Cotterill, Jill Fisch, Elizabeth de Fontenay, Anna Gelpern, Todd Gromley, David Musto, Un Kyung Park, Stefano Rossi, Christopher Spink, Christoph 


\section{Introduction}

The Greek debt restructuring of March 2012 was one of the biggest and most brutal in the long history of sovereign debt restructurings. The vast majority of creditors-holders of ordinary Greek sovereign bonds-took the proverbial axe to the neck, suffering net present value ("NPV") haircuts of close to $80 \%$ (Zettelmeyer et al., 2013). Greece forced acquiescence to its terms by using a number of legal strong-arm tactics. And with the majority of Greek bonds, the tactics worked. There were, however, thirty-six bonds guaranteed by the Greek state that, because of the weakness of the underlying companies, were effectively obligations of the Greek state - imposing an obligation on Greece similar to ordinary Greek sovereign bonds. Yet, on these thirty-six bonds, Greece did not attempt any strong-arm tactics. The investors holding these Greek guaranteed bonds (assuming they did not choose voluntarily to take the $80 \%$ cut) earned a windfall relative to holders of ordinary Greek sovereign bonds. The question at the center of our project is simple: Did the markets recognize, ahead of time, that the guarantee bonds were going to be treated preferentially by Greece in the March 2012 restructuring and price this preference? To unpack that query, we have to answer a prior question of: What produced that advantage?

The answer we heard from those close to the restructuring was that the favorable treatment that guaranteed bonds received vis-à-vis ordinary Greek sovereign bonds in the March 2012 restructuring of Greece's debt was primarily the result of contractual differences that made the guaranteed bonds harder to restructure than the ordinary sovereign bonds. That answer, in combination with the Euro area crisis of 2010-2013 throws up an opportunity to test an age-old question: What is the extent to which markets price legal differences due to differing contractual provisions?

The existing literature on sovereign bonds is unclear on the answer to the question of whether contract terms are priced. Some research suggests that key contract terms are priced and other research suggests that they are not (Häseler, 2009). Evidence does exist, however, that legal difference with respect to governing law matters (Chamon et al., 2014). In the 2012 Greek restructuring itself, English law governed bonds received better treatment than local law bonds because they had strong contract terms and Greek legislative fiat could not reach them because of the protection afforded by English law. Japanese and Swiss law governed bonds did even better than the English law bonds in the restructuring because of the additional regulatory hoops imposing a haircut on the Japanese and Swiss law governed bonds would

Trebesch, Landon Thomas, Jeromin Zettelmeyer, participants at workshops at the European University in Florence, Harvard Law School, USC Law School, Wharton Business School/Penn Law School, Washington \& Lee Law School and two anonymous referees for comments. 
have entailed (Zettelmeyer et al., 2013). Finally, bonds held by the European Central Bank (ECB) did not take any haircuts in the restructuring because of legal restrictions prohibiting monetary financing by ECB (Black, 2012, quoting Mario Draghi's February 9 statement on the ECB's rationale for refusing to take losses on its Greek bond holdings).

We use the natural experiment thrown up by the Euro area sovereign debt crisis of 2010-2013 to test the pricing question. Our natural experiment compares the market pricing of two instruments, ordinary sovereign bonds and sovereign guaranteed bonds, that impose roughly similar financial obligations on the state but differ in their contract terms. At the height of the Euro area debt crisis in 2011-2012, almost every Eurozone sovereign issuer had both ordinary and guarantee bonds outstanding. The vast majority of the bonds for each sovereign were ordinary sovereign bonds with few contract protections (termed "sovereign bonds"). And then there were a minority of bonds that were guaranteed debt, where the sovereign had typically provided the guarantee to help one of its distressed local firms to issue bonds (termed "guarantee bonds"). The fortunes of these local firms, particularly to the extent they were financial institutions - as were many firms receiving guarantees during the crisis - were tied closely to those of the sovereign because a major asset of these financial firms would typically be bonds of their own sovereign. If the sovereign went into default, the financial firm was sure to fail as well (absent some external bailout). In that case, the guarantee bonds would just get converted into the equivalent of ordinary sovereign bonds. Or so one might think.

The fly in the buttermilk, as it was explained to us by practitioners, was in the contract terms governing how the guarantee would be triggered for investors of the guarantee bonds. The guaranteed bonds enjoyed two specific contractual term protections that the ordinary sovereign bonds typically did not have: the right to declare an "Event of Default" and the absence of a "Collective Action Clause". In good times, when the likelihood of a sovereign default seemed distant, we expect that these contractual terms made little difference and that guarantee bonds would be priced similarly with equivalent ordinary sovereign bonds. However, as the sovereign approaches default, we expect that these specific contractual provisions would lead investors to value guarantee bonds more than the equivalent ordinary sovereign bond, leading to a pricing differential. ${ }^{1}$

Why do these contract terms in the sovereign guarantee bond matter as the sovereign approaches default? The right to trigger default in a guarantee bond is, as one might expect, given to the investor. When the primary obligor on the bond stops paying, violates one of its key covenants, or if the guarantor goes into financial distress, the investor has the option, to declare an "Event of

\footnotetext{
${ }^{1}$ Prior research suggests that guaranteed bonds for developed sovereigns, because of a liquidity premium, tend to be valued more by the markets than their guaranteed counterparts, even though the two sets of bonds produce the same financial payouts (Langstaff, 2004).
} 
Default". We refer to this as the investor's call provision. Assuming that the primary obligor is not able to cure the problem within a specified period of time (usually 15 to 30 days) the investor can convert his guarantee bond into a sovereign obligation. The investor who converted would then have a sovereign debt instrument that would get restructured like every other sovereign bond of that issuer. ${ }^{2}$

A smart investor though might see that it was in his interest to refrain from triggering his guarantee right away, even if he was not getting paid his coupon payments. What if he did this? The sovereign would restructure its outstanding sovereign debt. That is, force an exchange of all of its old sovereign bonds for new bonds paying some small fraction of the amounts promised on the prior bonds. As noted earlier, for Greece in 2012, the NPV haircut was close to $80 \%$. Because the guarantee bonds would not be in default (since the investor chose not to trigger an Event of Default) and in any case the obligation was directly that of a private issuer and not the sovereign, the sovereign would not have the ability to restructure the guarantee bonds. As a result, the investor with the guarantee bond who refrained from triggering his guarantee might miss out on receiving a couple of coupon payments, but would also escape the sovereign's restructuring and resulting haircut. After the restructuring concludes, history tells us that the sovereign will begin paying its new restructured obligations in full so as to be able to regain market access. It is at this stage that the holder of the guarantee bond who refrained from triggering it earlier, will call his guarantee, exchanging the guarantee bonds for new sovereign obligations. ${ }^{3}$ The sovereign, having only recently gone through the enormous cost and pain that debt defaults bring will be unwilling to go back into default so soon after having escaped it. ${ }^{4}$ The guarantee bondholders,

\footnotetext{
${ }^{2}$ Bonds can vary in terms of the operation of the right to trigger an Event of Default in that it is sometimes vested in an individual creditor and sometimes requires a $25 \%$ of the creditors to trigger it. In the text, we have simplified the dynamics of how the conversion of the guarantee bond to a sovereign obligation occurs. As a technical matter, what occurs is not a conversion to a sovereign obligation, but a conversion of a contingent obligation of the sovereign into an actual one. Specifically, one where the investor now has the option to seek payment from either the primary obligor $(\mathrm{PO})$ or the guarantor $(\mathrm{G})$. For those interested, this is how it works: When the Event of Default occurs, the investor has the option of accelerating his underlying bond. If that is not immediately paid, the investors can call on the separate, independent guarantee to cover the defaulted payment. As a formal matter, at this point the investor still has his claim against the $\mathrm{PO}$, but he also has a parallel, independent claim against the G. If either the PO or the G pays the claim in full, that payment discharges both claims simultaneously. In the discussion in the text, we have assumed away the POs on the grounds that most of them were extremely weak. Including them would complicate our analysis, but the implications of our results would remain the same.

${ }^{3} \mathrm{Or}$, if the sovereign, as a result of the restructuring, now has funds to renew funding to the companies that had the guarantees, the guarantee holder's situation is even better. Best we can tell, this is what seems to have happened in Greece.

${ }^{4}$ For a discussion of the typical reluctance of governments to declare defaults, which is seen as one of the major problems with sovereign debt (Buchheit et al., 2013).
} 
now holding the new sovereign obligations, will get paid in full, especially if there are not too many of them. ${ }^{5}$

In theory, the sovereign could get around the foregoing problem by trying to restructure the guarantees directly, as contingent obligations, even without the Event of Default having been triggered. When we asked the "Why didn't you try this?" question of the lawyers involved with the Greek 2012 restructuring, we received the answer that while we had indeed raised a theoretical possibility, it would have been difficult to implement in practice for at least three reasons. First, there would be the valuation nightmare of figuring out how much of a haircut to apply to each contingent obligation, given that the contingency had not been called - something that would presumably need to take into consideration the finances of the various underlying POs. Second, and more significantly, there would need to be a contractual mechanism to squeeze the potential holdouts in any contingent debt restructuring (Collective Action Clauses or CACs). And, it turns out that almost no sovereign guaranteed bonds have CACs that would help restructure the sovereign's contingent obligations. ${ }^{6}$ Third, for the small subset of the guaranteed bonds issued under Greek local law, where a CAC could have been legislatively been superimposed on the bonds, there was still the matter of whether the guarantee bonds would need to be offered a higher exchange price than the regular holders (on account of the additional legal protections in the guarantee bonds). ${ }^{7}$ And agreement on that matter turned out to be difficult to achieve.

In sum, this potential advantage based on the value to investors of the right to trigger an Event of Default, the lack of a CAC in the guarantee bonds, and the general fact that the restructuring of the guarantees would be complicated, was not an obvious one. To our minds, this advantage would have been available only to those savvy investors who had seen how prior sovereign restructurings had worked in the past and recognized the inherent advantages in the guaranteed bonds. Indeed, prior to the Eurozone crisis, there had been no public discussion of this potential advantage for holders of guarantees. ${ }^{8}$ In hindsight, we know that some investors recognized this

\footnotetext{
${ }^{5}$ It is potentially important that there be a relatively small number of guaranteed bonds so that the sovereign does not have an incentive to try and circumvent the contractual advantage that the guarantee bondholders have.

${ }^{6}$ Of the thousand plus bonds we have coded for our project, only a handful of bonds guaranteed by the UK have turned up with CACs that apply to the guarantee part of the contract. Many of these bonds had CACs that applied to the primary obligation, but the drafters had failed to include CACs for the secondary or contingent portion of the obligation.

${ }^{7}$ Twelve of the 36 guaranteed bonds that went into the Greek restructuring were under local law. From what we hear, the specific arguments were over how much more the guaranteed bonds under local law would need to be offered than the regular bonds, on account of their better legal standing. Failure to offer them better terms, the concern was, might lead to legal claims for expropriation. In the end, no attempt was made to restructure either type of guaranteed bond.

${ }^{8}$ One might be able to read an implicit discussion of this strategy into some of the articles written in the wake of Belize's restructuring in 2008, where one large holder of guaranteed
} 
advantage - a Dutch bank, ABN Amro in particular - and profited handsomely during the Greek debt restructuring of 2012 (Bouras and Granitsas, 2012; Dutch Bank Hands Greece Set Back, 2012). At least some other holders of the guarantees do not appear to have recognized this advantage because they voluntarily tendered their guaranteed bonds in the restructuring, taking the same haircut as the regular sovereign bonds. ${ }^{9}$ The question then is whether ABN Amro and the others that similarly chose not to exercise their call provision during the crisis were just lucky or did the smart money more generally recognize this opportunity ahead of time?

The scenario as sketched out above took place in Greece, and to a lesser extent the other "PIIGS" countries including Portugal, Italy, Ireland, and Spain, in 2012. To reiterate, the holders of Greek guaranteed bonds who refrained from voluntarily submitting their bonds in the March 2012 restructuring, got paid in full while almost all the other sovereign bondholders received an NPV haircut of around $80 \%$. If the market had recognized this advantage ahead of time, we should see that recognition reflected in the relative pricing of guarantee bonds and ordinary sovereign bonds as the crisis was worsening. And we should see it reflected not only in the prices for Greek bonds, but for all of the other countries that went into crisis as well, such as Ireland, Spain Italy, and Portugal.

To test whether the markets recognized the investment advantage described above, we use a hand-collected dataset of over 1,800 sovereign bonds and guarantee bonds issued from 2000 to early 2014. This time period is useful for purposes of our study because it has three distinct phases. First, there is the phase of great optimism, from 2000 to early 2010, where the markets are so confident about the prospects of the Euro area that they are essentially treating all of the major Euro area credits as similar to Germany (that is risk free). Then, in early 2010, the crisis hits Greece and spreads quickly to the other so-called PIIGS countries (Portugal, Ireland, Italy, and Spain) and borrowing rates for these governments begin looking like those of weak emerging market issuers. ${ }^{10}$ In March 2012, Greece does one of the biggest

debt escaped the restructuring. See Belize Bank: A $\$ 10$ M Mystery, The Economist, May $15,2008$.

${ }^{9}$ It is hard to tell precisely how many holders of the guarantee instruments recognized the advantage they had because Greece did not try to bring the vast majority of its guaranteed debts into the March 2012 exchange. Anecdotal approximations are that there were in the vicinity of 500 separate guarantee instruments (bonds and loans) outstanding at the time of the restructuring. Of the thirty-six that were brought into the March 2012 exchange, the majority of holders did voluntarily enter the exchange. But we cannot tell whether they did so because these particular holders were affiliates of one of the Euro area governments (and therefore under political pressure) or whether they did not understand the contractual advantage they had. For details on the guarantee bonds and the exchange, to the extent they are available, see Zettelmeyer et al. (2013).

${ }^{10}$ For an illustration of how, in early 2010 , the estimated probability of default for Greece, and then the other PIIGS moved sharply upwards in 2010 and then moved 
restructurings in history, imposing brutal haircuts on its creditors, but still ending up with a large debt stock that needs to be serviced. Subsequently, the Euro area markets begin to recover slowly, in fits and starts, and it takes until early 2014 for normalcy to return. That then gives us three distinct periods to look at pricing. The "Pre Crisis" period prior to April 2010 where default likelihoods were considered near zero. The "Crisis" period from April 2010 to March 2012 when default likelihoods for the PIIGS countries were dramatically higher (and Greece effectively did default). And then the "Post Crisis" recovery period from April 2012 to the end of our study period in August 2014, where the markets were still jittery, but gradually calmed down.

Our key finding is consistent with the view that contract terms are priced. In the Pre Crisis period, we find little evidence of the guarantee advantage being priced. This may mean that investors during this period do not recognize the contractual advantage provided by guaranteed bonds over sovereign bonds or, alternatively, the risk of default is sufficiently small that yields will not change much with the presence of the contract advantage. ${ }^{11}$ In the Crisis period, a different pattern emerges. The market appears to wake up to the value of the legal advantage in the guarantees as default becomes a greater likelihood for certain sovereigns and the legal advantage begins to get priced in.

The pricing pattern in the Post Crisis recovery stage, however, is not as easy to explain. What we should see here for Greece and the other PIIGS is something in-between the Pre Crisis and Crisis periods. In concrete terms, the yields on guarantee bonds should be lower than those on sovereign bonds during this Post Crisis recovery period, but not as much lower as they were during the Crisis period. What we see instead, and especially so for Greece, is that the yields on guarantee bonds shoot above those of comparable sovereign bonds in the Post Crisis recovery period. Our investigation though suggests that the reported yields for many of the Post Crisis Greek guaranteed bonds may have been fake.

Section 2 sets for the motivation and methodology behind our pricing tests of contract terms. Section 3 surveys the relevant literature. Section 4 describes our dataset. Section 5 reports our test results. Section 6 discusses possible reasons for the changes in bond price yields in the Post Crisis period. Section 7 concludes.

over the 2010-2013 period, see http://personal.vu.nl/s.j.koopman/projects/ScoreWork Shop2013/BSchwaab_ScoreModels_17Jan13 3.pdf

${ }^{11}$ We cannot dismiss the possibility though that the probability of default was so low in the Pre Crisis period that the value of the contract advantage was dwarfed by the liquidity benefit associated with holding a sovereign bond as opposed to more thinly traded guarantee bonds. 


\section{The Pricing Tests}

\subsection{Framework for the Pricing Tests}

The market for government securities is one of the oldest, most robust, markets in the world and one dominated by sophisticated institutional players. In theory, the pricing question should be an easy matter to test in the market for government securities. The ideal test would use pricing data from the same issuer that issued multiple sovereign bonds into the market place at about the same time but that used different terms. Preferably, the bonds would be of similar maturity, similar offering amount, and issued in a similar time period and differ only along the one contract term dimension in question. Given such data, one could compare the prices of financial instruments containing one type of contract term against those that lack it, keeping everything else constant. In reality, the foregoing comparisons are difficult to do because issuers rarely issue bonds that are comparable in terms of differences in one or two contract terms.

To solve the problem, researchers have looked to cross sectional comparisons across different sovereign issuers. But there are problems with cross sectional comparisons, ones that we hope to ameliorate with our comparison of guarantee and sovereign bonds from the same sovereign.

First, different sovereign issuers using the different terms-for example, a high rated issuer like the Netherlands versus a low rated issuer like Sri Lanka - tend to differ not only in terms of their economic characteristics, but across a host of contract terms. By contrast, issuers of the same economic class, by contrast - for example, low rated issuers like Sri Lanka and Vietnam-tend to use identical contract terms. The heroic assumption that has to be made by those employing cross sectional analysis is that any pricing differentials that show up are the result of the one term that is the subject of the study in question. All other differences, including differences in other contract terms that can number in the dozens and the overall economic situation of countries from different economic classes that are not explicitly controlled for in the cross sectional test, are assumed irrelevant.

Second, and this is the more significant problem, any particular sovereign will tend to issue bonds all with identical contractual provisions. A cross sectional analysis across sovereign issuers will therefore provide information on the value of a term when used uniformly by a particular sovereign. The pricing of the term will include a particular aspect of pricing - what one might call the signaling aspect. What we see in the cross sectional analysis then is what the effect is of Azerbaijan having one type of covenant in all its bonds (for example, a negative pledge clause) and Italy not having that clause in all its bonds. Because of the absence of that clause, the Italian bonds as a whole will be easier to restructure in a crisis than the ones from Azerbaijan. At the point 
at which these bonds are marketed, investors might make different inferences about the likelihood of a future crisis from the signal that Italy is unwilling to offer negative pledge clauses and Azerbaijan is. ${ }^{12}$ Those inferences in turn will impact prices for Italian bonds as compared with Azerbaijani bonds. Any pricing study of the clause will include both the underlying value of the term in affecting the prospective cash flows for an investor in the bonds as well as the signal-related value on the probability of default from the sovereign's use of the clause.

Looking at the pricing of a contract term in guarantee bonds allows us to isolate the underlying value of the contract term from any signaling effect precisely because the sovereign is not associated directly with the term (and instead is associated with the terms in the more prevalent sovereign bonds). Moreover, because now the sovereign faces obligations to repay from bonds with potentially different contractual rights for investors, we are able to study an additional element of pricing: the subordination effect. A subordination effect in pricing should occur when, for example, we observe Azerbaijan issuing some debt instruments that have negative pledge clauses and others that do not. In any insolvency situation, the debtor has a limited pool of assets to distribute. ${ }^{13}$ Given that governments cannot liquidate, the government debtor essentially has to decide from which creditors to extract relief. The answer to that question will depend on what the relative level of contract protection the different debt instruments of the issuer have. Other things equal, the debtor will logically seek the maximal amount of relief from the debts that have the weakest legal protections. Put differently, in a sovereign insolvency, debt instruments with weaker contract provisions are de facto subordinated to those that have stronger provisions (Zettelmeyer and Gulati, 2012). We therefore expect to see more subordinated instruments receive a higher yield compared with less subordinated ones.

But how does one study the subordination effect? After all, the same sovereign issuers rarely issue bonds that differ in terms of the contract terms they use. Our example of Azerbaijan issuing some bonds with and some bonds without a negative pledge clause rarely exists. All bonds issued by Azerbaijan within a comparable time frame will typically have the exact same terms. Moreover, the value of subordination is greatest when a sovereign issuer is near financial distress. Examining two bonds from the same sovereign with

${ }^{12}$ These inferences do not necessarily have to be different. An investor might view the omission of a negative pledge clause from the bonds of a rich developed nation as positive (because rich nations can be trusted and should not be constrained) and that same investor might also view the presence of a negative pledge clause in the bond of a poor developing country as a positive (because poor nations are going to be tempted to default and need to be constrained).

${ }^{13}$ To a limited extent, this pool can become bigger if the country can avail itself of bailout funds from outside, which may in some cases be a function of what contract terms it has. The way in which this dynamic works is described by Bradley and Gulati (2014). 
and without a negative pledge clause - even if such data existed - would likely understate the pricing impact of subordination for a sovereign in financial distress if the sovereign in question is financially strong.

The Euro area sovereign debt crisis, which ran roughly between early 2010 and early 2014, gives us a natural experiment that allows us to surmount some of the problems described in the preceding text. What happened in the Euro area crisis that has not happened in any other recent sovereign debt crisis is that, during the crisis, a large number of government guaranteed bonds as opposed to ordinary sovereign bonds were issued to the market (Buchheit and Gulati, 2013). The reason this happened during the Euro area crisis, but had not happened in any of the prior sovereign crises of the past half-century, is that countries that get into debt crises tend to be weak at the outset. When the crisis hits, they typically lose market access and have to turn to non-market sources of funding such as the IMF. Such sovereigns are simply unable to guarantee the debt of private issuers or issue their own sovereign debt.

The Euro area crisis was different. The crisis hit rich European countriesnations that that were never supposed to default. Because of the wealth of the European countries, investors continued to be willing to lend to these countries on a relatively large scale even after the crisis began. Prior to the crisis, each of the nations that subsequently went into crisis (the so-called PIIGS), already had a large stock of what one might call naked sovereign bonds. That is, government bonds with few contract provisions. When the crisis hit, and markets began focusing on things like the high Debt/GDP ratios of these countries, these countries began issuing large numbers of bonds not through their treasuries directly, but through private issuers in the form of guaranteed bonds.

The specific reasons why these governments turned to guarantee bonds as their method of financing during the crisis are unclear. Our understanding from discussions with market participants is that there was a combination of factors. Initially, the crisis that hit (roughly, around Sept 2008) was not a sovereign debt crisis; instead, it stemmed from the Lehman induced contraction in bank financing. ${ }^{14}$ Providing sovereign guarantees to the private financial firms who were not able to access the markets on their own was seen as a cheap strategy by many nations who were strong credits. By 2010 though, the crisis had hit the sovereigns themselves. At this stage, because the same financial firms who were being provided assistance via guarantees were also the primary purchasers of government securities, the guarantees helped indirectly to bolster the markets for government securities (see Merler and Pisani-Ferry (2012) about this this interdependence in the Euro Area). Further, these contingent liabilities had lower visibility than garden variety government debt issuances.

\footnotetext{
${ }^{14}$ See Euro Area Fiscal Policies and the Crisis, ECB Working Paper \#109 (April 2010) (describing the use of guarantee schemes by many sovereigns to help domestic financial firms in the 2008-2010 period).
} 
They did not, for example, get counted either in the general debt levels for purposes of compliance with Maastricht Treaty requirements or most other public Debt/GDP calculations (Buchheit and Gulati, 2013).

Regardless of reason, the Euro area sovereigns ended up with a large number of sovereign bonds and guaranteed bonds at the same time. The end result then was that we had (a) sovereign issuers who had different types of instruments (guarantee and sovereign bonds) outstanding at the same time that that had different de facto priority levels in case of a sovereign default, (b) prices available for both instruments, and (c) prices available in particular during a crisis situation allowing us to study the pricing impact of subordination during financial distress.

\subsection{Pricing Hypotheses}

We focus our tests on the difference in yields between guarantee bonds and the yields for comparable sovereign bonds matched by the issue date and term of the guarantee bond. We refer to the difference in guarantee bond and sovereign bond yields as the Spread. Thus, a more positive Spread indicates that the guarantee bond has a higher yield than the comparable sovereign bond yield. Because for any guarantee bond and comparable sovereign bond the sovereign in question stands behind both instruments, we start from the assumption that the Spread will be at or near zero. Of course, other factors may affect the Spread, including the relative liquidity of the guarantee and sovereign bonds, the availability of the private issuer's assets in addition to the sovereign's to repay a guarantee bond but only the sovereign's assets to repay the sovereign bond, and any differential likelihood that the sovereign may make good on its obligation for one type of instrument but not the other.

Looking at the Spread allows us to test for the presence of a subordination effect in the pricing of bonds. If there is a subordination effect, we should see a specific relationship emerge in the yields for sovereign bonds and guarantee bonds, as the sovereign moves from normal times into a debt crisis. In good times, the sovereign bond of a developed country is a sought after asset - it is liquid (there is a lot of it out there) and it is probably priced more accurately than most other assets (because of the number of analysts following it). Relative to this sovereign bond, the guarantee bond is clumsy and unwieldy in good times. If the company goes under, creditors might face hurdles in converting their guarantee into a regular sovereign obligation. ${ }^{15}$ Further, the amount of guarantee bonds from a specific private issuer at any given time in the market is not large compared with the amount of comparable sovereign bonds, which means that traders will be uncertain as to how to price the guarantee bonds and they will tend to avoid them. The prior literature on guarantees tells us

\footnotetext{
${ }^{15}$ Practitioners have described this to us as "structural risk".
} 
that, most of the time, the yield on a guarantee bond is going to be higher than that on the regular sovereign bond, leading to a positive Spread.

As the good times turn into a crisis, however, the Spread should narrow and possibly invert and become negative as liquidity becomes less important and default becomes more likely. ${ }^{16}$ In a default situation, what one wants is an instrument that has unusual contract provisions (the opposite of liquidity). As explained in the introduction, the two key contract advantages that the guarantees possess are the right to call an Event of Default and the lack of a $\mathrm{CAC}$ that could force a restructuring of the sovereign's contingent obligation. These two advantages allow the guarantee holder to escape the pain of the restructuring, so long as he is smart enough to recognize them and act accordingly. Because this contract advantage is one that shows up in the context of a distressed restructuring, its value should increase as the crisis worsens and default approaches. In theory, there may be ways to get around these contract advantages and force the guarantee holders to convert their bonds (Buchheit and Gulati, 2013). But, so long as doing so is legally complicated and if there are not enough guarantee bonds outstanding to make the effort worthwhile for the sovereign, the guarantee bonds stand a good chance of escaping the restructuring entirely.

Other possible explanations exist for a narrowing of the Spread and eventual flipping of the Spread as a sovereign approaches default. While in good times, the value of the sovereign's backing of guarantee debt swamps other features of the private debt including the private issuer's own assets backing the debt, in bad times, the presence also of the private issuer's assets may lead investors to view guarantee debt more favorably than comparable sovereign debt. What is key though in distinguishing this alternative hypothesis is that the guarantee private issuers typically were financially weak private issuers who often would not have been able to tap the market without the benefit of a sovereign guarantee (they needed the guarantees precisely because they were weak). ${ }^{17}$ In our tests, we examine the financial strength of the private issuer where we were able to obtain credit rating data to distinguish this alternative hypothesis. If the alternative hypothesis were true, we should see that the most negative Spreads during the Euro zone crisis show up for the strongest private issuers. We find the opposite; the weakest private issuers correspond, if anything, with the higher negative Spreads during the crisis.

${ }^{16}$ This is not the prediction in the extant finance literature on government bonds versus guarantee bonds, which predicts the opposite - that there is a "flight to liquidity" when conditions worsen, which in turn suggests that the guaranteed instruments would become increasingly less valuable as the crisis worsen. See Langstaff (2004). This literature, however, does not take into consideration the impact of contract terms and does not consider issuers who go into deep crisis, as Greece and the other PIIGS nations did in 2010-2013.

${ }^{17}$ More generally, researchers on guaranteed instruments find that the primary determinant of the yield on such instruments is the strength of the sovereign guarantor rather than the underlying company receiving the guarantee. See Levy and Zaghini (2010). 
The data from the Euro area crisis allows us to test whether the market priced the value of the guarantee advantage across a range of countries, all of who went into the crisis, but did so to different degrees. It also allows us to compare what happened in the countries that were not hit by the crisis. The foregoing gives us our hypothesis.

Hypothesis: If the market prices the contract advantages of the guarantees, we should see the Spread gradually go from positive toward zero as the crisis worsens and flip to negative as default becomes highly likely. The one country that went into a default scenario during the time period of our study was Greece; the inversion in the Spread from positive to negative should, therefore, be the clearest for Greece.

\section{The Literature}

Government bonds are different in at least two important ways from corporate bonds, the focus of most of the existing research on the pricing of bond contract terms. First, governments are run by politicians and not by managers; and politicians respond to voters, rather than investors. Second, governments generally do not hesitate to manipulate the market prices for their securities, twist the arms of rating agencies, and force institutions like domestic banks to buy and hold these securities. All of that is to say that our expectation of rational pricing of contract terms in a government bond should be less than what it is for corporate bonds.

The focus of the research on the pricing of contract terms in government bonds has been on one contract term, the Collective Action Clause or CAC (Häseler, 2009). A CAC is a provision that allows for a supermajority of creditors to vote to bind the entire creditor group on key matters such as the amount that is owed. The reason attention has been paid to the study of this term is that at least twice over the past two decades, major policy initiatives have been undertaken to persuade market actors that the adoption of these terms is beneficial to them and to the system as a whole. A question that was raised in resistance to these policy initiatives, unsurprisingly, was whether these contract reforms would raise the cost of capital for borrowers (Gelpern and Gulati, 2013). Despite the multiplicity of studies on the question of CAC pricing, there has been considerable variation in the findings; some finding price penalties, others finding price benefits and still others finding little or no pricing effects (Becker et al., 2003; Gugiatti and Richards, 2003; Eichengreen and Mody, 2004; Bardozetti and Dottori, 2013; Bradley and Gulati, 2014).

What almost all of these studies have in common is that they were studies of pricing that included the signaling effect. That is, the impact of the market 
seeing that all of the bonds for a particular issuer had or did not have CACs. None of them sought to get at the subordination effect, in terms of examining the impact of CACs in an issuer's bonds as compared to bonds of that same issuer without CACs. To the extent almost all of the outstanding bonds of the same sovereign issuers, except for a few isolated bond issuances here and there, had the same CAC term, studying subordination between different bonds was simply not possible. The guarantee context is one of the few where we find bonds backed by the same issuer that have de facto different priority due to the combination of the call provision inherent in guarantee bonds and the lack of a CAC applying to the guarantee, allowing us to test whether the market prices the reduction in value that comes from having subordinated bonds.

Other provisions in government debt contracts have received relatively little attention as compared to CACs. ${ }^{18}$ One area where the subordination effect has been examined (albeit, not identified as such) is with governing law, a provision that we examine as well. The same sovereign issuer will often issue bonds governed by foreign law (usually either English or New York) and also bonds governed by local law. To the extent it is easier to restructure bonds under local law, such bonds will tend to get restructured first and thus be de facto subordinate to bonds governed under foreign law in times of financial distress.

Researchers have examined whether markets demand a higher yield for local law governed bonds as compared to the foreign law bonds of the same sovereign. The findings are that for the richer countries, there is not much of a premium charged for the use of local law-probably a reflection of the fact that default probabilities for these issuers are extremely low and there is value attached to liquidity. For the financially weaker nations, however, the markets do grant issuers a discount if they utilize foreign law instead of local law; a discount that becomes larger as economic conditions worsen (Choi et al., 2011; Chamon et al., 2014; Clare and Schmidlin, 2014).

Turning to the question of whether markets price the contract advantages of guaranteed sovereign bonds over regular sovereign bonds (our focus), there are no studies that we are aware of that examine this question. There are a number of studies that examine the spread in yields between guarantee bonds and sovereign bonds (precisely what we do), but the assumption that these studies make is that the legal differences are irrelevant to pricing (Langstaff, 2004; Ejsing et al., 2012; Schuster and Uhrig-Homburg, 2013). Unlike our

\footnotetext{
${ }^{18}$ There are also studies that have measured the impact of external changes on the meaning of contract terms. The types of external changes are judicial interpretations or statutory reforms. Among the clauses that have been examined in this form are waivers of sovereign immunity, pari passu clauses and gold clauses. These studies though, while arguably measuring the pricing impact of a change in the meaning of a contract provision, may also be measuring changes in the broader economic context (which they induce either statutory or judicial change). See, for example, Weidemaier (2014), Bradley et al. (2010), Kroszner (1998 draft), Alfaro et al. (2010).
} 
study, however, these studies limit themselves to the examination of Spreads for the highest credit quality sovereigns. What they predict (and find) is that there is a liquidity premium for investment in sovereign bonds relative to guarantee bonds; a premium that increases as financial conditions worsen and there is the proverbial "flight to liquidity". In other words, the prediction is the opposite of the one that we make. The caveat being that these prior studies examine the highest rated issuers (the U.S., France and Germany), for whom default probabilities never become high and, therefore, contract terms such as the call provision are never meaningfully implicated. We move now to testing the hypotheses laid out in the prior section.

\section{Dataset}

We use data on guarantee bond issuances from January 2000 to August 2014. To generate this data, we utilized sovereign bond prospectuses and offering circulars from the three primary databases for such material: Perfect Information, Thomson One Banker and Dealogic. We hand coded these prospectuses for the key financial and contract variables, giving us a dataset of around 1000 observations. For an additional set of a roughly 800 issuances, we were unable to obtain the offering documents, but were able to obtain the key contract variables from Dealogic. In sum, this produced a dataset of 1,886 guaranteed bonds. ${ }^{19}$ While our search procedure may have missed some bonds, we do not have any evidence that there was any systematic tendency for our procedure to miss bonds from a particular geographic region or related to any of our other variables of interest. Where the bond provided for a floating rate, we determined the rate for the benchmark used in the floating rate and computed the rate as of the issuance date. Note that because many of the guarantee bonds were not traded in a liquid market, we focused our analysis on how the market priced the yield as of the initial issuance of the guarantee bond. Table 1 reports of the year breakdown of the sovereign guaranteed private bonds in our dataset.

For each guarantee bond in our dataset, we used Bloomberg to determine the yield on a sovereign bond issued by the sovereign providing the guarantee. We determined the comparable sovereign bond by matching based on currency of the private bond and the maturity term of the bond and looking at the sovereign bond yield curve computed by Bloomberg from the issuance date of the private bond. Where the yield curve provided by Bloomberg did not provide a sovereign bond yield for the specific maturity term of the private

\footnotetext{
${ }^{19}$ For a subset of a few hundred bonds, prospectuses or offering circulars were not available. However, the basic information on the key terms - particularly, the governing law variable - we needed was available on Dealogic. Unreported, we ran our analyses both with and without the additional Dealogic bonds and obtained roughly the same results.
} 


\begin{tabular}{lccccc}
\hline Year & $\begin{array}{c}\text { All } \\
\text { Countries }\end{array}$ & Greece & $\begin{array}{c}\text { Other } \\
\text { PIIGS }\end{array}$ & $\begin{array}{c}\text { Non-PIIGS } \\
\text { Europe }\end{array}$ & $\begin{array}{c}\text { Outside } \\
\text { Europe }\end{array}$ \\
\hline 2000 & 48 & 1 & 31 & 3 & 13 \\
2001 & 55 & 0 & 50 & 2 & 3 \\
2002 & 71 & 4 & 55 & 2 & 10 \\
2003 & 66 & 3 & 46 & 9 & 8 \\
2004 & 74 & 7 & 53 & 5 & 9 \\
2005 & 44 & 2 & 34 & 3 & 5 \\
2006 & 46 & 2 & 36 & 1 & 7 \\
2007 & 54 & 2 & 40 & 6 & 6 \\
2008 & 100 & 2 & 56 & 38 & 4 \\
2009 & 456 & 5 & 305 & 113 & 33 \\
2010 & 240 & 26 & 170 & 36 & 8 \\
2011 & 200 & 15 & 164 & 11 & 10 \\
2012 & 277 & 8 & 226 & 25 & 18 \\
2013 & 134 & 13 & 71 & 33 & 17 \\
2014 & 21 & 5 & 16 & 0 & 0 \\
Total & 1886 & 95 & 1353 & 287 & 151 \\
\hline
\end{tabular}

Table 1: This table reports the year breakdown of the sovereign guaranteed private bonds in our dataset for all countries and for our four groupings of countries by year. The four groupings are: (1) Greece, (2) the other European countries that neared financial distress during the sovereign debt crisis (Portugal, Ireland, Italy, and Spain or the "Other PIIGS"), (3) all the other European nations ("Non-PIIGS Europe") and (4) those countries outside of Europe ("Outside Europe").

bond, we extrapolated between the yields for the next shorter and next longer maturity terms for which Bloomberg reported a yield number for the sovereign bond if available.

\section{Empirical Tests}

For our tests, we divide our dataset into three time periods. We define those private bonds issued before April 2010 as issued in the "Pre Crisis" time period. ${ }^{20}$ We also divide our dataset based on specific groupings of countries as a function of how badly they were impacted by the European sovereign debt crisis: (1) Greece, (2) the other European countries that neared

\footnotetext{
${ }^{20}$ It is hard to pinpoint exactly when the sovereign debt part of the crisis started and commentators give various dates ranging from late December 2009 to April 2010. April 2010 is a commonly used date and was when the crisis was recognized as one by the Euro area governments in that a Euro 30 bn package of emergency loans for Greece was approved (Aglietta, 2011). Our results would remain much the same though were we to use some of the earlier dates in 2010 that have also been proposed as starting points of the crisis.
} 
financial distress during the sovereign debt crisis (Portugal, Ireland, Italy, and Spain or the "Other PIIGS"), (3) all the other European nations ("Non-PIIGS Europe") and (4) those countries outside of Europe ("Outside Europe"). It bears emphasizing that the set of nations that are able to issue substantial numbers of guaranteed bonds is comprised overwhelmingly of those in the investment grade range. Emerging market issuers are rarely able to issue guaranteed bonds on the international markets, presumably because their credit is not strong enough to act as a backstop.

In the Pre-Crisis period, all of the sovereigns for which we have yield spread data are investment grade. Figure 1 plots how far a sovereign's S\&P credit rating is from the highest junk rating $(\mathrm{BB}+)$. $\mathrm{A}$ score of 0 on the plot is a $\mathrm{BB}+$ rating; a score of +1 is one notch above junk (BBB-); a score of -1 is one notch below $\mathrm{BB}+$ (or $\mathrm{BB})$. All positive scores in the plot are investment grade. All sovereigns before April 2010 are investment grade, although a number are less than 5 notches above junk status. We utilize these close-to-junk sovereigns in our tests for the importance of default risk. We expect the Spread to respond according to our hypotheses detailed above. For a financially strong
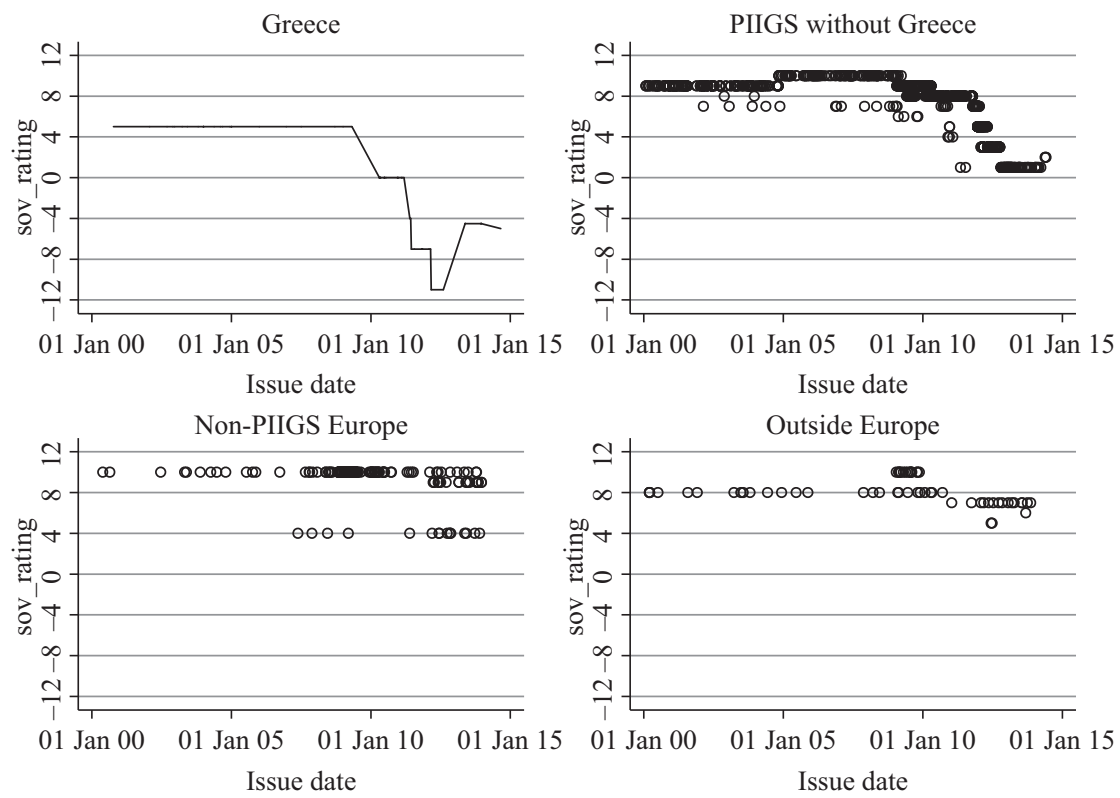

Figure 1: Sovereign S\&P Ratings. The figure plots how far a sovereign's S\&P credit rating is from the highest junk rating $(\mathrm{BB}+)$. A score of 0 on the plot is a $\mathrm{BB}+$ rating; a score of +1 is one notch above junk (BBB-); a score of -1 is one notch below BB+ (or $\mathrm{BB}$ ). All positive scores in the plot are investment grade. All sovereigns before April 2010 are investment grade, although a number are less than 5 notches above junk status. 
sovereign, we should see a more positive Spread. The Spread should then be more negative for the Sovereign Near Junk category where the sovereign is financially weaker than the other investment grade sovereigns.

We look to the Pre Crisis period to establish a baseline on how the market prices (if at all) different characteristics of a private bond relative to a comparable sovereign bond outside of the recent sovereign debt crisis. Table 1 reports the number of sovereign guaranteed issuances for our four groupings of countries by year. Note that only in 2010, and in particular after the end of the Pre Crisis period, did Greece rapidly increase its guarantees of private bond debt. Both the Other PIIGS and Non-PIIGS Europe countries also increased their numbers of guarantees, although both of these groups increased the number of guarantees a little earlier than Greece toward the end of the Pre Crisis period.

We define those guaranteed bonds issued from April 2010 to March 2012 as in the "Crisis" time period. We use March 2012 as the point at which the crisis begins to turn around because it is when the Greek restructuring takes place. Long-term yields for Euro area sovereigns begin to drop at this point. ${ }^{21}$ We look at the difference between those countries most affected by the crisis - Greece and the Other PIIGS - and the other countries in our sample - the Non-PIIGS Europe and Outside Europe countries. We assess how this difference changes from the Pre Crisis to the Crisis period. This difference-in-difference framework allows us to assess how the market adjusted its pricing of the contract advantages in the guarantees as the sovereign neared financial distress.

Lastly, we define those private bonds issued from April 2012 to August 2014 as in the "Post Crisis" recovery period. We use March 2012 as the end of the crisis because this is when Greek yields return to the Pre Crisis levels and Greek financial institutions begin to be able to access the markets again (Chaturvedi, 2014; Moore and Hope, 2014). We again look at the difference between those countries most affected by the crisis - Greece and the Other PIIGS - and the other countries in our sample - the Non-PIIGS Europe and Outside Europe countries. We assess how this difference changes from the Pre Crisis to the Post Crisis period. This difference-in-difference framework allows us to assess whether the market reverts back to a more "normal" pricing of a sovereign guarantee once the sovereign backs away from financial distress and begins to regain financial strength.

\subsection{Pre Crisis Baseline}

The Pre Crisis period establishes our baseline for our difference-in-difference framework for how the market prices guaranteed bonds relative to sovereign

\footnotetext{
${ }^{21}$ The data are available, both in tabular and numerical form from the ECB, from their statistical data warehouse. http://www.ecb.europa.eu/stats/money/long/html/index.en.html
} 


\begin{tabular}{|c|c|c|c|c|c|}
\hline & $N$ & Mean & $\begin{array}{c}t \text {-test } \\
p \text {-value }\end{array}$ & Median & $\begin{array}{c}\text { Wilcoxon Rank } \\
\text { Sum } p \text {-value }\end{array}$ \\
\hline \multicolumn{6}{|l|}{ Greece } \\
\hline Pre Crisis & 23 & -0.002 & - & 0 & - \\
\hline Crisis & 41 & -0.944 & 0.029 & -0.089 & 0 \\
\hline Post Crisis & 8 & 0.074 & 0 & 0.077 & 0 \\
\hline \multicolumn{6}{|l|}{ Other PIIGS } \\
\hline Pre Crisis & 649 & -0.001 & - & 0.002 & - \\
\hline Crisis & 394 & 0.005 & 0 & 0.006 & 0 \\
\hline Post Crisis & 11 & 0.006 & 0 & 0.006 & 0 \\
\hline \multicolumn{6}{|c|}{ Non-PIIGS Europe } \\
\hline Pre Crisis & 144 & 0.004 & - & 0.006 & - \\
\hline Crisis & 18 & 0 & 0.051 & 0.001 & 0.046 \\
\hline Post Crisis & 39 & 0.003 & 0.352 & 0.002 & 0.084 \\
\hline \multicolumn{6}{|c|}{ Outside Europe } \\
\hline Pre Crisis & 39 & 0.015 & - & 0.010 & - \\
\hline Crisis & 7 & 0.014 & 0.891 & 0.013 & 0.725 \\
\hline Post Crisis & 14 & 0.003 & 0.099 & -0.001 & 0.090 \\
\hline
\end{tabular}

Table 2: This table provides summary statistics for the spread. The spread is defined as the difference between the guaranteed bond yield and the corresponding sovereign bond yield matched by the issue date and term of the guarantee bond. For our tests, we divide our dataset into three time periods as discussed in the text. We define those private bonds issued before April 2010 as issued in the "Pre Crisis" time period. We define those guaranteed bonds issued from April 2010 to March 2012 as in the "Crisis" time period. Lastly, we define those private bonds issued from April 2012 to August 2014 as in the "Post Crisis" recovery period. We also divide our dataset based on specific groupings of countries as a function of how badly they were impacted by the European sovereign debt crisis: (1) Greece, (2) the other European countries that neared financial distress during the sovereign debt crisis (Portugal, Ireland, Italy, and Spain or the "Other PIIGS"), (3) all the other European nations ("Non-PIIGS Europe") and (4) those countries outside of Europe ("Outside Europe").

Note: $t$-test $p$-value is in comparison with the Pre Crisis mean. Wilcoxon Rank sum $p$-value is in comparison with the Pre Crisis median.

bonds. For our comparison we compute the Spread between the guaranteed bond yield and the corresponding sovereign bond yield. Table 2 provides summary statistics for the Spread for our four groupings of countries and the three time periods.

Note from Table 2 that the mean and median Spread in Greece in the Pre Crisis period are both close to zero, indicating that the market priced Greek guaranteed bonds close to comparable Greek sovereign bonds in the Pre Crisis period. A similar pattern exists in the Pre Crisis period for the Other PIIGS and Non-PIIGS Europe; the market priced sovereign guarantee 
private bonds similar with the comparable sovereign bond with a mean and median Spread at or below 60 basis points in the Pre Crisis period. Outside of Europe, the market generally priced guaranteed bonds with a higher yield than comparable sovereign bonds, leading to a positive Spread, in the Pre Crisis period. In other words, what we see in the Pre Crisis period is consistent with the suggestion in the literature that there tends to be a liquidity premium for sovereign bonds, making them more attractive than guaranteed bonds (Langstaff, 2004; Schuster and Uhrig-Homburg, 2013).

To assess more specifically the factors that affect the Spread, we estimate an ordinary least squares model with the log of 1 plus the Spread as the dependent variable using errors clustered by the country granting the guarantee. We estimate the model only for bonds guaranteed by sovereigns within Europe. The model is as follows:

$$
\begin{aligned}
\ln \left(1+\text { Spread }_{i}=\right. & \alpha+\beta_{1 i} \ln (\text { Amount })_{i}+\beta_{2 i} \text { Investment Grade }_{i} \\
& +\beta_{3 i} \text { Foreign Law }_{i}+\beta_{4 i} \text { Greece }_{i} \\
& +\beta_{5 i} \text { Other PIIGS }_{i}+\varepsilon_{i}
\end{aligned}
$$

In our first model, we assess the relationship between the dependent variable and the log of the offering amount $(\ln$ (Amount)) and whether the private issuer is investment grade $(=1)$ or not $(=0)$ at the time of the bond issuance (Investment Grade). We include an indicator variable for whether the guarantee bond is governed under foreign law (Foreign Law). The use of local law (as opposed to foreign law) makes restructuring a private guarantee bond easier and, therefore, should result in higher Spreads all other things being equal. We also add indicator variables for Greece (Greece) and the PIIGS without Greece (Other PIIGS) to test whether even in the Pre Crisis period, investors were altering their pricing of the private bonds relative to comparable sovereign bonds due to the increasing riskiness of Greece and to a lesser extent the Other PIIGS and possible Non-PIGGS Europe countries. Against Greece and the Other PIIGS, our base category is the group of other countries in Europe that issued guaranteed bonds in our sample. Table 3 reports summary statistics on the independent variables. The model is reported as Model 1 in Table 4.

In Model 1, the coefficient on $\ln$ (Amount) is positive and significant at the $1 \%$ level. The size of any particular guarantee bond offering is positively correlated with the Spread. One possible factor affecting the Spread is the likelihood that a sovereign may ignore guarantee bonds for restructuring purposes where a small aggregate amount of guarantee bonds are outstanding but not ignore guarantee bonds when larger amounts of the guarantee bonds are outstanding.

In Model 1, we also do not find evidence that the financial strength of the private issuer, as indicated by credit ratings, matters for the Spread. The 


\begin{tabular}{lcccc}
\hline Variable & $N$ & Mean & Median & $\begin{array}{c}\text { Standard } \\
\text { Deviation }\end{array}$ \\
\hline Amount (millions of Euros) & 1344 & 522.8 & 154.8 & 942.1 \\
Investment Grade & 1537 & 0.679 & 1.000 & 0.467 \\
Foreign Law & 1533 & 0.648 & 1.000 & 0.478 \\
Greece & 1537 & 0.047 & 0 & 0.211 \\
Other PIIGS & 1537 & 0.783 & 1.000 & 0.412 \\
Non-PIIGS Europe & 1537 & 0.131 & 0 & 0.337 \\
Close to Junk & 1537 & 0.165 & 0 & 0.371 \\
\hline
\end{tabular}

Table 3: This table reports summary statistics on the independent variables used in the regression models reported in Tables 4,5 , and 6 . The independent variables include the log of the offering amount ( $\ln ($ Amount $))$ and whether the private issuer is investment grade $(=1)$ or not $(=0)$ at the time of the bond issuance (Investment Grade). The independent variables also include an indicator variable for whether the guarantee bond is governed under foreign law (Foreign Law). The independent variables include indicator variables for Greece (Greece), the PIIGS without Greece (Other PIIGS), and Europe without the PIIGS (Non-PIIGS Europe). Lastly, Close to Junk is equal to 1 if $\mathrm{S} \& \mathrm{P}$ rates the sovereign (other than Greece) as less than 5 rating notches above the highest level of junk status at the time of a particular guarantee bond issuance and 0 otherwise.

coefficient on Investment Grade is not significantly different from zero. This is consistent with the premise that the sovereign's financial backing is the key determining factor behind the guarantee bond yield in good times such as in the Pre Crisis period of our study. We also do not find that Foreign Law is correlated with the Spread.

Turning to the relationship of Greece and the Spread, in Model 1, we find that Greece does not correlate with a significantly different Spread in the Pre Crisis period relative to the base category of Non-PIIGS Europe countries. We do find that the Other PIIGS countries correlate weakly (at the $10 \%$ confidence level) with a more negative Spread in the Pre Crisis period compared with the base category of other countries in Europe. This may suggest that even prior to the date we identify as the beginning of the Crisis, April 1, 2010, investors had perceived weaknesses at least for the Other PIIGS countries.

We re-estimate Model 1 for all countries in our sample and add an indicator variable for European countries without the PIIGS (Non-PIIGS Europe) using the countries outside Europe as the base category. We report the results in Model 2 of Table 4 . We obtain largely the same qualitative results in Model 2 as in Model 1. In addition, the coefficient on Non-PIIGS Europe is not significantly different from zero.

To test the importance of default risk for the sovereigns other than Greece, we re-estimate Model 2 of Table 4 and remove the Other PIIGS and NonPIIGS Europe indicator variables and associated interaction terms and add an indicator variable for Close to Junk status. Close to Junk is defined as equal to 


\begin{tabular}{lccc}
\hline & $\begin{array}{c}\text { Model 1 } \\
\text { (Dependent } \\
\text { Variable = Spread })\end{array}$ & $\begin{array}{c}\text { Model 2 } \\
\text { (Dependent } \\
\text { Variable = Spread })\end{array}$ & $\begin{array}{c}\text { Model 3 } \\
\text { (Dependent } \\
\text { Variable = Spread) }\end{array}$ \\
\hline $\ln$ (Amount) & $0.002^{* *}$ & $0.002^{* *}$ & $0.003^{* *}$ \\
Investment Grade & $(5.80)$ & $(4.34)$ & $(4.55)$ \\
Foreign Law & 0.003 & 0.003 & 0 \\
& $(0.84)$ & $(0.78)$ & $(0.13)$ \\
Greece & -0.004 & -0.004 & -0.001 \\
& $(-1.51)$ & $(-1.49)$ & $(-0.42)$ \\
Other PIIGS & -0.002 & -0.015 & -0.001 \\
& $(-0.77)$ & $(-1.59)$ & $(-0.23)$ \\
Non-PIIGS Europe & $-0.005^{+}$ & $-0.018^{+}$ & \\
Close to Junk & $(-2.11)$ & $(-1.93)$ & $-0.005^{* *}$ \\
Constant & & -0.014 & $(-3.01)$ \\
& & & $-0.014^{* *}$ \\
$N$ & $-0.006^{* *}$ & 0.005 & $(-7.77)$ \\
adj. $R^{2}$ & $(-3.33)$ & $(0.53)$ & 779 \\
\hline
\end{tabular}

Table 4: Difference-in-differences model of spread for the pre crisis period.

Note: $t$ statistics in parentheses; ${ }^{+} p<0.10,{ }^{*} p<0.05,{ }^{* *} p<0.01$.

Description: This table reports the regression results from an ordinary least squares model with the log of 1 plus the Spread as the dependent variable using errors clustered by the country granting the guarantee. Data observations are individual guarantee bond private issuances. Spread is defined as the difference between the guaranteed bond yield and the corresponding sovereign bond yield matched by the issue date and term of the guarantee bond. Time periods are defined in Table 2. In Model 1, we focus only on countries in Europe in the Pre Crisis period and assess the relationship between the dependent variable and the log of the offering amount $(\ln$ (Amount)) and whether the private issuer is investment grade $(=1)$ or not $(=0)$ at the time of the bond issuance (Investment Grade). We include an indicator variable for whether the guarantee bond is governed under foreign law (Foreign Law). We also add indicator variables for Greece (Greece) and the PIIGS without Greece (Other PIIGS). Against Greece and Other PIIGS, our base category is the group of all other countries in Europe that guaranteed bonds in our sample. In Model 2, we re-estimated Model 1 for all countries in our sample and add an indicator variable for Non-PIIGS Europe countries with countries outside of Europe as the base category. In Model 3, we test the importance of default risk for the sovereigns other than Greece. In the model we use the same independent variables as in Model 2 but we remove the Other PIIGS and Non-PIIGS Europe indicator variables and add the Close to Junk indicator variable.

1 if $\mathrm{S} \& \mathrm{P}$ rates the sovereign (other than Greece) as less than 5 rating notches above the highest level of junk status at the time of a particular guarantee bond issuance and 0 otherwise. We report the results in Model 3 of Table 4. Note that the coefficient on Close to Junk is negative and significant at the $1 \%$ level, indicating that the Spread is more negative for sovereigns that are Close to Junk in status. ${ }^{22}$

${ }^{22}$ We re-defined the Close to Junk variable as equal to 1 if $\mathrm{S} \& \mathrm{P}$ rates the sovereign (other than Greece) as less than or equal to 3 rating notches above the highest level of junk status at the time of a particular guarantee bond issuance and 0 otherwise. For the Pre-Crisis 


\subsection{Crisis Period}

During the Crisis period, investors focused closely on Greece and the Other PIIGS and the increasing likelihood during this period that these countries would default on their sovereign obligations. We use the Crisis period to assess how the Spreads changed when the market's perception of a particular sovereign, including Greece and the Other PIIGS, shifted from strong to weak.

Table 2 reports that the mean Spread in the Crisis period for Greece was -0.944 compared with a Pre Crisis spread of -0.002 (difference significant at the $5 \%$ level), representing a large magnitude 9,420 basis point negative shift in the Spread compared with Pre Crisis period. As conditions in Greece worsened, investors holding guarantee bonds presumably began attaching greater value to their contractual right to call the guarantee bonds - something that would have likely helped them do well in a restructuring as compared to the naked sovereign bonds. From Table 2 also note that the mean Spread in the Crisis period for the Other PIIGS was 0.005 compared with a mean Pre Crisis Spread of -0.001 . This difference is significant at the $1 \%$ level. However, the magnitude of the mean shift was not large, representing only a 60 basis point positive shift in the Spread. Lastly, note that the mean Spread became more negative for the Non-PIIGS Europe and Outside Europe countries in the Crisis compared with Pre Crisis periods, although the shift was only significant for the Non-PIIGS Europe countries. Overall then, as the crisis hit, the guaranteed bonds increased in value relative to their plain vanilla sovereign bond counterparts.

To test the differential impact of the Crisis on Greece and the Other PIIGS in relation to other factors that affect the Spread, we estimate an ordinary least squares model with the log of 1 plus the Spread as the dependent variable using errors clustered by the country granting the guarantee. We estimate the model only for bonds guaranteed by sovereigns within Europe. The model is as follows:

$$
\begin{aligned}
\ln \left(1+\text { Spread }_{i}=\right. & \alpha+\beta_{1 i} \ln (\text { Amount })_{i}+\beta_{2 i} \text { Investment Grade }_{i} \\
& +\beta_{3 i} \text { Foreign Law }_{i}+\beta_{4 i} \text { Greece }_{i}+\beta_{5 i} \text { Other PIIGS }_{i} \\
& +\beta_{6 i} \text { Crisis }_{i}+\beta_{7 i} \text { Greece }_{i} \times \text { Crisis }_{i} \\
& +\beta_{8 i} \text { Other PIIGS }_{i} \times \text { Crisis }_{i}+\varepsilon_{i}
\end{aligned}
$$

The model uses the same independent variables as in Model 1 of Table 4. To estimate the shift that occurs in the Spread due to the Crisis, we add an indicator variable for the Crisis period (Crisis). For our difference-in-difference

Period, however, we did not have any observations that fit this criteria and for which we had data on the Spread. 
tests, we add interaction terms between Greece, the Other PIIGS, and the NonPIIGS Europe countries and Crisis (Greece $\times$ Crisis and Other PIIGS $\times$ Crisis). Model 1 of Table 5 reports the results from the model.

In Model 1 of Table 5, the coefficient on Crisis is not significantly different from zero. Across all countries in our sample, we find no general shift in investor views of the relative risk of guarantees compared with sovereign bonds during the Crisis period. Turning to those countries most directly affected by the Crisis, Greece experienced the most negative publicity during the Crisis and investors in Greece's sovereign bonds faced the greatest risk of default. Unsurprisingly, therefore, the coefficient on Greece $\times$ Crisis in Model 1 is negative and significant at the $1 \%$ level. The magnitude of the shift in the Spread for guaranteed bonds for Greece is also economically meaningful. The Spread for Greek guaranteed bonds decreases by approximately $8.0 \%$ from the Pre Crisis to Crisis period. In other words, as the crisis worsens, investors begin to value having a guarantee bond more relative to the underlying sovereign bond. Our conjecture, given that the underlying entities receiving the guarantees were almost all weak institutions, is that this shift occurred because investors realized that when the restructuring occurred, the guarantees were less likely to be restructured than the regular sovereign bonds.

In contrast to the negative and significant coefficient for Greece $\times$ Crisis, in Model 1 the coefficient on Other PIIGS $\times$ Crisis is positive and significant at the $1 \%$ level. Compared with Greece, investors had a higher value of guarantees from the Other PIIGS countries relative to the baseline Non-PIIGS Europe countries during the Crisis period. These results for the Other PIIGS are somewhat puzzling since the crisis hit them as well, though not as hard as it did Greece. Note that S\&P continued to rate the Other PIIGS as investment grade throughout the Crisis period unlike Greece which entered junk and eventually default status.

We re-estimate Model 1 for all countries in our sample and add an indicator variable for European countries without the PIIGS (Non-PIIGS Europe) using the countries outside Europe as the base category. We report the results in Model 2 of Table 5 . We obtain largely the same qualitative results in Model 2 as in Model 1 with one difference: the coefficient on Other PIIGS $\times$ Crisis is positive but no longer significantly different from zero. In addition, the coefficient on Non-PIIGS Europe $\times$ Crisis is not significantly different from zero.

To test the importance of default risk for the sovereigns other than Greece, we re-estimate Model 2 of Table 5 and remove the Other PIIGS and Non-PIIGS Europe indicator variables and associated interaction terms and add the Close to Junk indicator variable and the Close to Junk $\times$ Crisis interaction term. We report the results in Model 3 of Table 5. In Model 3 of Table 5, note that Close to Junk $\times$ Crisis is negative and significant at the $5 \%$ level. The sum of Crisis and Close to Junk $\times$ Crisis is negative and significant at the $1 \%$ 


\begin{tabular}{|c|c|c|c|}
\hline & $\begin{array}{c}\text { Model } 1 \\
(\text { Dependent } \\
\text { Variable }=\text { Spread })\end{array}$ & $\begin{array}{c}\text { Model } 2 \\
(\text { Dependent } \\
\text { Variable }=\text { Spread })\end{array}$ & $\begin{array}{c}\text { Model 3 } \\
(\text { Dependent } \\
\text { Variable = Spread })\end{array}$ \\
\hline $\ln$ (Amount) & $\begin{array}{l}0.002^{* *} \\
(6.06)\end{array}$ & $\begin{array}{l}0.002^{* *} \\
(5.60)\end{array}$ & $\begin{array}{l}0.002^{* *} \\
(5.21)\end{array}$ \\
\hline Investment Grade & $\begin{array}{c}0.003 \\
(0.94)\end{array}$ & $\begin{array}{c}0.003 \\
(0.91)\end{array}$ & $\begin{array}{c}0.001 \\
(0.32)\end{array}$ \\
\hline Foreign Law & $\begin{array}{c}-0.003 \\
(-1.29)\end{array}$ & $\begin{array}{l}-0.003 \\
(-1.27)\end{array}$ & $\begin{array}{l}-0.001 \\
(-0.47)\end{array}$ \\
\hline Greece & $\begin{array}{l}-0.002 \\
(-1.10)\end{array}$ & $\begin{array}{c}-0.016 \\
(-1.58)\end{array}$ & $\begin{array}{l}-0.001 \\
(-0.20)\end{array}$ \\
\hline Other PIIGS & $\begin{array}{l}-0.005^{*} \\
(-2.22)\end{array}$ & $\begin{array}{l}-0.018^{+} \\
(-1.88)\end{array}$ & \\
\hline Non-PIIGS Europe & & $\begin{array}{l}-0.013 \\
(-1.42)\end{array}$ & \\
\hline Close to Junk & & & $\begin{array}{l}-0.005^{*} \\
(-2.43)\end{array}$ \\
\hline Crisis & $\begin{array}{c}-0.003 \\
(-1.54)\end{array}$ & $\begin{array}{c}-0.006 \\
(-0.67)\end{array}$ & $\begin{array}{c}0.002 \\
(1.36)\end{array}$ \\
\hline Greece $\times$ Crisis & $\begin{array}{c}-0.080^{* *} \\
(-67.19)\end{array}$ & $\begin{array}{l}-0.078^{* *} \\
(-8.44)\end{array}$ & $\begin{array}{c}-0.087^{* *} \\
(-99.67)\end{array}$ \\
\hline Other PIIGS $\times$ Crisis & $\begin{array}{l}0.007^{* *} \\
(4.76)\end{array}$ & $\begin{array}{c}0.010 \\
(1.06)\end{array}$ & \\
\hline Non-PIIGS Europe $\times$ Crisis & & $\begin{array}{c}0.003 \\
(0.37)\end{array}$ & \\
\hline Close to Junk $\times$ Crisis & & & $\begin{array}{l}-0.019^{*} \\
(-2.65)\end{array}$ \\
\hline Constant & $\begin{array}{l}-0.006^{* *} \\
(-3.47)\end{array}$ & $\begin{array}{c}0.005 \\
(0.54)\end{array}$ & $\begin{array}{l}-0.013^{* *} \\
(-9.46)\end{array}$ \\
\hline $\begin{array}{l}N \\
\text { adj. } R^{2}\end{array}$ & $\begin{array}{l}1062 \\
0.520\end{array}$ & $\begin{array}{l}1108 \\
0.509\end{array}$ & $\begin{array}{l}1108 \\
0.493\end{array}$ \\
\hline
\end{tabular}

Table 5: Difference-in-differences model of spread for the pre crisis and crisis periods.

Note: $t$ statistics in parentheses; ${ }^{+} p<0.10,{ }^{*} p<0.05,{ }^{* *} p<0.01$.

Description: This table reports the regression results from an ordinary least squares model with the log of 1 plus the Spread as the dependent variable using errors clustered by the country granting the guarantee. Data observations are individual guarantee bond private issuances. Spread is defined in Table 4. Time periods are defined in Table 2. In Model 1, we focus only on countries in Europe for the Pre Crisis and Crisis periods and assess the relationship between the dependent variable and the log of the offering amount (ln (Amount)) and whether the private issuer is investment grade $(=1)$ or not $(=0)$ at the time of the bond issuance (Investment Grade). We include an indicator variable for whether the guarantee bond is governed under foreign law (Foreign Law). We also add indicator variables for Greece (Greece) and the PIIGS without Greece (Other PIIGS). Against Greece and Other PIIGS, our base category is the group of all other countries in Europe that guaranteed bonds in our sample. To estimate the shift that occurs in the Spread due to the Crisis, we include an indicator variable for the Crisis period (Crisis). For our difference-in-difference tests, we also include interaction terms between Greece and the Other PIIGS and Crisis (Greece $\times$ Crisis and Other PIIGS $\times$ Crisis). In Model 2, we re-estimated Model 1 for all countries in our sample and add an indicator variable for Non-PIIGS Europe countries with countries outside of Europe as the base category and an interaction term for Non-PIIGS $\times$ Crisis. In Model 3, we test the importance of default risk for the sovereigns other than Greece. In the model we use the same independent variables as in Model 2 but we remove the Other PIIGS and Non-PIIGS Europe indicator variables and associated interaction terms and add the Close to Junk indicator variable and the Close to Junk $\times$ Crisis interaction term. 
level. For those sovereigns close to junk in their credit rating status, the crisis correlates with a decrease in the Spread relative to the Pre Crisis period. ${ }^{23}$

In sum, guarantee bonds as a whole receive a lower yield compared with the matched sovereign bond yield as the sovereign approaches default. Greece is the one country that goes into default and the Spread drops by an economically meaningful amount for Greek guarantee bonds during the Crisis period. The Spread similarly drops in the Crisis period for sovereigns close to junk status. This is consistent with the importance of the legal advantages in the guarantee bonds that we discussed earlier.

To distinguish whether the Spread is lower in the Crisis period because of the alternate hypothesis that guarantee bonds offer investors the assets of not only the sovereign but also the private issuer, we compared the investment grade status of the private issuers whose debt was guaranteed by Greece in the Crisis period. Thirty-eight (or 92.7\%) of the 41 issuances guaranteed by Greece in the Crisis period were below investment grade. The mean spread for the junk status private issuers moreover was -1.01 compared with a mean spread of -0.06 for the investment grade issuers, indicating that if anything, the reduction in the Spread is due to the junk status private issuers - inconsistent with the alternative hypothesis (difference not statistically significant however).

\subsection{Post Crisis Recovery}

In March 2012, Greece conducted its mega restructuring. ${ }^{24}$ By April 2012, Greece, while far from returning to a financial strength, was on the road to recovery. For this Post Crisis Recovery period, our expectation was that those forces that drove guarantee bond yields much lower than sovereign bond yields during the Crisis period, particularly for Greece and to a lesser extent the Other PIIGS, would partially reverse themselves but would not recover to the Pre Crisis levels. As we will see, they do reverse. But, at least for Greece, this reversal does not occur in a fashion that looks remotely rational from an investor perspective.

Table 2 reports that the mean Spread in the Post Crisis period for Greece was 0.074 compared with a Pre Crisis spread of -0.002 (difference significant at the $1 \%$ level), representing a 742 basis point positive shift in the Spread compared with the Pre Crisis period. This is a large shift, and puzzling when put into context. Only months prior, during the March 2012 restructuring, ordinary Greek sovereign bonds had been brutally and mandatorily restructured

\footnotetext{
${ }^{23}$ We re-defined the Close to Junk variable as equal to 1 if $\mathrm{S} \& \mathrm{P}$ rates the sovereign (other than Greece) as less than or equal to 3 rating notches above the highest level of junk status at the time of a particular guarantee bond issuance and 0 otherwise. We replaced the Close to Junk $\times$ Crisis interaction term with an interaction term between the re-defined Close to Junk variable and Crisis in Model 3 of Table 5. Unreported, we obtained the same qualitative results as in Model 3 of Table 5.

${ }^{24} I d$.
} 
and the guaranteed bonds had only received a polite request to voluntarily enter the restructuring. This difference in treatment was almost entirely driven by two factors. First, there were relatively few guarantee bonds outstanding as compared to a huge number of sovereign bonds outstanding. Second, there were going to be many more complex legal issues to be tackled in a restructuring of guarantee bonds than with the sovereign bonds. In the post April 2012 period, there were many fewer sovereign bonds outstanding, but still a high volume of them relative to the number of guarantee bonds. And the legal challenges with restructuring a guarantee bond remained the same. So, why did Spreads invert? ${ }^{25}$

To confirm our summary statistic findings, we graphed the private bond yield against the comparable sovereign yield for each issuance by Greece during the Pre Crisis, Crisis, and Post Crisis periods. Because the yield shifts dramatically during the Crisis period, we break the Crisis period into two sub periods - Early Crisis and Late Crisis - for purposes of the graph. Figure 2 depicts the graphs for Greece. Note from Figure 2 that in the Pre Crisis period for Greece, the Greek guarantee bond yield was generally at or slightly below the comparable Greek sovereign bond yield.

Things change in the Early Crisis, with a shift upward in the yield for Greek sovereign bonds. While Greek guarantee yields also increase in the Early Crisis, they do not increase as much as the Greek sovereign bond yields, leading to a more negative Spread. This trend continues in the Late Crisis period with a large magnitude shift in the Greek sovereign bond yield without a corresponding increase in the guarantee yield. Greece's deteriorating financial position resulted in investors making calculations regarding which of the Greek bonds were more or less likely to be impacted negatively in a restructuring. Investors appear to have anticipated what happened eventually, which was that the guarantees were less likely to be hurt in a restructuring than the regular bonds. The widening negative Spread in the Late Crisis period suggests that investors were behaving in a sophisticated fashion in terms of calculating which Greek bonds were more vulnerable and which ones were less so.

In the Post Crisis period, after the Greek restructuring of March 2012, we expected to see that as Greece returned to some semblance of financial stability, the large negative Spreads we observed in the Early and Late Crisis periods would diminish (the likelihood of another Greek restructuring was getting

\footnotetext{
${ }^{25}$ When we turn to the results for the other nations, we see numbers that are more normal. The mean Spread in the Post Crisis period for the Other PIIGS was 0.006 compared with a mean Pre Crisis Spread of -0.001 . This difference is significant at the $1 \%$ level. However, the magnitude of the mean shift was not large, representing only a 70 basis point positive shift in the Spread. In comparison to Greece and the Other PIIGS, the mean Spread became more negative for the Non-PIIGS Europe and Outside Europe countries in the Post Crisis compared with Pre Crisis periods, although the shift was significant only for the Outside Europe countries (at the 10\% level).
} 

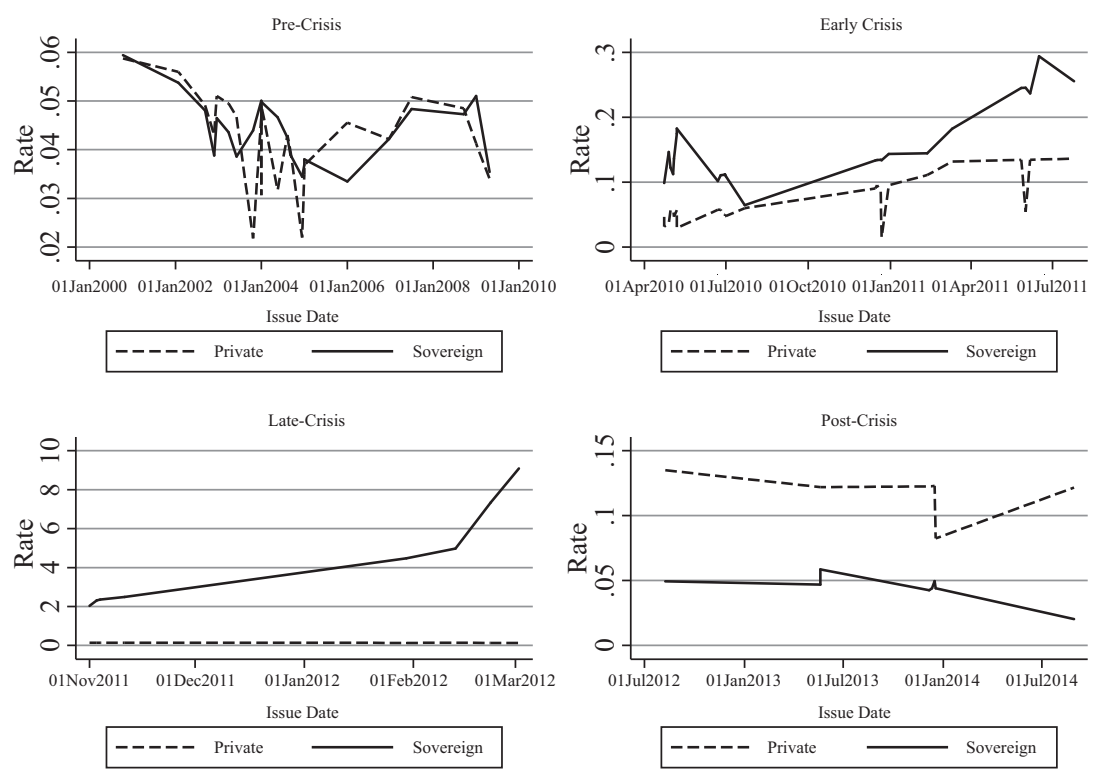

Figure 2: Spreads for Greek guaranteed bonds. The figure plots the private bond yield against the comparable sovereign yield for each issuance by Greece during the Pre Crisis, Crisis, and Post Crisis periods. Table 2 defines the time periods. Because the yield shifts dramatically during the Crisis period, we break the Crisis period into two sub periods-Early Crisis and Late Crisis - for purposes of the figure.

smaller during this period) ${ }^{26}$ And as things improved in Greece, the spread should have returned to a level similar in the Pre Crisis baseline. Figure 2 shows that this is not what happened for Greece. Rather than approach the Pre Crisis Spread, the Spread for Greece flipped to a large positive Spreadroughly a 900 basis point positive Spread. As noted earlier, given how the market priced sovereign guaranteed private bonds relative to the comparable sovereign bond in the Pre Crisis and Crisis periods, and given what investors surely learned from the experience of the Greek restructuring (guarantee bonds were harder to restructure than regular sovereign bonds), the sudden shift upward in the Spread for Greek in the Post Crisis period is a puzzle.

We also examined the private bond yield against the comparable sovereign yield for each issuance guaranteed by the other sovereigns during the Pre Crisis, Crisis, and Post Crisis periods. As with Greece, the private bond yield is similar to the sovereign bond yield in the Pre Crisis period for the other sovereigns, although if anything the sovereign yields are higher than the guarantee bond yields. Unlike for Greece, we are unable to discern a consistent difference in the Spread in the Early and Late Crisis periods for the other sovereigns.

\footnotetext{
${ }^{26}$ These figures are available on the ECB website. See supra note 21.
} 
To test whether the shift in Spread for Greece and the Other PIIGS relative to the Non-PIIGS Europe countries persists once other factors affecting the Spread are controlled for, we estimate an ordinary least squares model with the $\log$ of 1 plus the Spread as the dependent variable using errors clustered by the country granting the guarantee. We estimate the model only for bonds guaranteed by sovereigns within Europe. The model is as follows:

$$
\begin{aligned}
\ln \left(1+\text { Spread }_{i}=\right. & \alpha+\beta_{1 i} \ln (\text { Amount })_{i}+\beta_{2 i} \text { Investment Grade }_{i} \\
& +\beta_{3 i} \text { Investment Grade }_{i}+\beta_{4 i} \text { Greece }_{i} \\
& +\beta_{5 i} \text { Other PIIGS }_{i}+\beta_{6 i} \text { Crisis }_{i} \\
& +\beta_{7 i} \text { Greece }_{i} \times \operatorname{Crisis}_{i}+\beta_{8 i} \text { Other PIIGS }_{i} \times \operatorname{Crisis}_{i} \\
& +\beta_{9 i} \text { Post Crisis }_{i}+\beta_{10 i} \text { Greece }_{i} \times \text { Post Crisis }_{i} \\
& +\beta_{11 i} \text { Other PIIGS }_{i} \times \text { Post Crisis }_{i}+\varepsilon_{i}
\end{aligned}
$$

The model is the same as Model 1 of Table 5 with the addition of an indicator variable for the Post Crisis period. For our difference-in-difference tests, we also use interaction terms between Greece and Other PIIGS and the Post Crisis indicator variable (Greece $\times$ Post Crisis and Other PIIGS $\times$ Post Crisis). Model 1 of Table 6 reports the results.

In Model 1 of Table 6 , the coefficient Greece $\times$ Crisis is negative and significant at the $1 \%$ level, similar with Model 1 of Table 5 . The coefficient on Post Crisis is not significantly different from zero. For the base category of Non-PIIGS Europe countries, the Post Crisis period is not correlated with a change in Spreads. In contrast, the coefficient on Greece $\times$ Post Crisis is positive and significant at the $1 \%$ level. The magnitude of the coefficient is large, corresponding to a $6.9 \%$ increase in the Spread. This is an economically meaningful positive shift in the Spread in the Post Crisis period for Greek guarantee bonds. The sum of Post Crisis + Greece $\times$ Post Crisis is also positive and significant at the $1 \%$ level, indicating that the Spread in the Post Crisis period for Greece is larger than the baseline Pre Crisis Spread.

While investors viewed Greece as in a better financial position Post Crisis compared with the Crisis period, we believe that it is unlikely that investors viewed Greece as in a better financial position Post Crisis compared with how investors viewed Greece in the Pre Crisis period. In the Pre Crisis period, investors viewed Greece as not that different from Germany in terms of sovereign credit risk. Nonetheless, the Spread in the Post Crisis Period for Greece is significantly more positive compared with the Pre Crisis period. Despite Greece's continuing weak financial position and the higher probability that the sovereign was not going to make good on its own sovereign obligations relative to its guarantee obligations (leading again to a more negative Spread), the Greek guaranteed private bonds were sold with a large positive Spread in the Post Crisis Period. That tells us that investors viewed the guarantee bonds 
in the Post Crisis period as far riskier than their ordinary sovereign bond cousins. As noted earlier, that shift in perception of investors, particularly when compared with the negative Spread in the Crisis period, is a mystery to us since the lesson investors should have learned from the Greek crisis and restructuring was the opposite - that guarantee bonds are relatively safe assets.

\begin{tabular}{|c|c|c|c|}
\hline & $\begin{array}{c}\text { Model 1 } \\
\text { (Dependent } \\
\text { Variable = Spread })\end{array}$ & $\begin{array}{c}\text { Model } 2 \\
(\text { Dependent } \\
\text { Variable }=\text { Spread })\end{array}$ & $\begin{array}{c}\text { Model } 3 \\
(\text { Dependent } \\
\text { Variable = Spread })\end{array}$ \\
\hline $\ln$ (Amount) & $\begin{array}{l}0.002^{* *} \\
(6.07)\end{array}$ & $\begin{array}{l}0.002^{* *} \\
(5.39)\end{array}$ & $\begin{array}{l}0.002^{* *} \\
(5.11)\end{array}$ \\
\hline Investment Grade & $\begin{array}{c}0.002 \\
(0.89)\end{array}$ & $\begin{array}{c}0.002 \\
(0.85)\end{array}$ & $\begin{array}{l}0 \\
(0.20)\end{array}$ \\
\hline Foreign Law & $\begin{array}{l}-0.003 \\
(-1.41)\end{array}$ & $\begin{array}{l}-0.003 \\
(-1.37)\end{array}$ & $\begin{array}{l}-0.001 \\
(-0.52)\end{array}$ \\
\hline Greece & $\begin{array}{l}-0.003 \\
(-1.58)\end{array}$ & $\begin{array}{l}-0.016 \\
(-1.57)\end{array}$ & $\begin{array}{l}-0.001 \\
(-0.28)\end{array}$ \\
\hline Other PIIGS & $\begin{array}{l}-0.005^{*} \\
(-2.48)\end{array}$ & $\begin{array}{l}-0.018^{+} \\
(-1.83)\end{array}$ & \\
\hline Non-PIIGS Europe & & $\begin{array}{l}-0.013 \\
(-1.35)\end{array}$ & \\
\hline Close to Junk & & & $\begin{array}{l}-0.005^{*} \\
(-2.56)\end{array}$ \\
\hline Crisis & $\begin{array}{l}-0.003 \\
(-1.66)\end{array}$ & $\begin{array}{l}-0.005 \\
(-0.56)\end{array}$ & $\begin{array}{c}0.003 \\
(1.42)\end{array}$ \\
\hline Greece $\times$ Crisis & $\begin{array}{l}-0.080^{* *} \\
(-60.29)\end{array}$ & $\begin{array}{l}-0.078^{* *} \\
(-8.20)\end{array}$ & $\begin{array}{l}-0.087^{* *} \\
(-94.79)\end{array}$ \\
\hline Other PIIGS $\times$ Crisis & $\begin{array}{l}0.007^{* *} \\
(4.69)\end{array}$ & $\begin{array}{c}0.009 \\
(0.96)\end{array}$ & \\
\hline Non-PIIGS Europe $\times$ Crisis & & $\begin{array}{r}0.002 \\
(0.26)\end{array}$ & \\
\hline Close to Junk $\times$ Crisis & & & $\begin{array}{l}-0.019^{*} \\
(-2.63)\end{array}$ \\
\hline Post Crisis & $\begin{array}{r}0.001 \\
(0.82)\end{array}$ & $\begin{array}{l}-0.014 \\
(-1.24)\end{array}$ & $\begin{array}{c}0.003 \\
(0.71)\end{array}$ \\
\hline Greece $\times$ Post Crisis & $\begin{array}{l}0.069^{* *} \\
(58.13)\end{array}$ & $\begin{array}{l}0.084^{* *} \\
(7.29)\end{array}$ & $\begin{array}{c}0.065^{* *} \\
(35.92)\end{array}$ \\
\hline $\begin{array}{l}\text { Other PIIGS } \times \\
\text { Post Crisis }\end{array}$ & $\begin{array}{l}0.008^{* *} \\
(6.03)\end{array}$ & $\begin{array}{c}0.023^{+} \\
(2.00)\end{array}$ & \\
\hline $\begin{array}{l}\text { Non-PIIGS Europe } \times \\
\text { Post Crisis }\end{array}$ & & $\begin{array}{c}0.015 \\
(1.37)\end{array}$ & \\
\hline Close to Junk $\times$ Post Crisis & & & $\begin{array}{l}0.010^{* *} \\
(3.07)\end{array}$ \\
\hline Constant & $\begin{array}{l}-0.004^{*} \\
(-2.68)\end{array}$ & $\begin{array}{r}0.007 \\
(0.69)\end{array}$ & $\begin{array}{l}-0.011^{* *} \\
(-9.86)\end{array}$ \\
\hline
\end{tabular}

Table 6: Difference-in-differences model of spread for all periods. 


\begin{tabular}{lccc}
\hline & $\begin{array}{c}\text { Model 1 } \\
\text { (Dependent }\end{array}$ & $\begin{array}{c}\text { Model 2 } \\
\text { (Dependent }\end{array}$ & $\begin{array}{c}\text { Model 3 } \\
\text { Vependent }\end{array}$ \\
\hline$N$ & Variable = Spread) & Variable = Spread) & Variable = Spread) \\
adj. $R^{2}$ & 1270 & 1330 & 1330 \\
\hline
\end{tabular}

Table 6: Continued.

Note: $t$ statistics in parentheses; ${ }^{+} p<0.10,{ }^{*} p<0.05,{ }^{* *} p<0.01$.

Description: This table reports the regression results from an ordinary least squares model with the log of 1 plus the Spread as the dependent variable using errors clustered by the country granting the guarantee. Data observations are individual guarantee bond private issuances. Spread is defined in Table 4. Time periods are defined in Table 2. In Model 1, we focus only on countries in Europe and assess the relationship between the dependent variable and the log of the offering amount $(\ln$ (Amount)) and whether the private issuer is investment grade $(=1)$ or not $(=0)$ at the time of the bond issuance (Investment Grade). We include an indicator variable for whether the guarantee bond is governed under foreign law (Foreign Law). We also add indicator variables for Greece (Greece) and the PIIGS without Greece (Other PIIGS). Against Greece and Other PIIGS, our base category is the group of all other countries in Europe that guaranteed bonds in our sample. To estimate the shift that occurs in the Spread due to the Crisis, we include an indicator variable for the Crisis period (Crisis). For our difference-in-difference tests, we also include interaction terms between Greece and the Other PIIGS and Crisis (Greece $\times$ Crisis and Other PIIGS $\times$ Crisis). To estimate the shift that occurs in the Spread in the Post Crisis period we include an indicator variable for Post Crisis. For our difference-in-difference tests, we also include interaction terms between Greece and the Other PIIGS and Post Crisis (Greece $\times$ Post Crisis and Other PIIGS $\times$ Post Crisis). In Model 2, we re-estimated Model 1 for all countries in our sample and add an indicator variable for Non-PIIGS Europe countries with countries outside of Europe as the base category and add interaction terms for Non-PIIGS Europe $\mathrm{x}$ Crisis and Non-PIIGS Europe x Post-Crisis. In Model 3, we test the importance of default risk for the sovereigns other than Greece. In the model we use the same independent variables as in Model 2 but we remove the Other PIIGS and Non-PIIGS Europe indicator variables and associated interaction terms and add the Close to Junk indicator variable and the Close to Junk $\times$ Crisis and Close to Junk $\times$ Post Crisis interaction terms.

The coefficient on Other PIIGS $\times$ Post Crisis is also positive and significant at the $1 \%$ level. The sum of Post Crisis + Other PIIGS $\times$ Post Crisis is positive and significant at the $5 \%$ level. Similar with Greece, the Spread for the Other PIIGS country is more positive relative to the Pre Crisis period despite the likely continued higher risk posed to investors by the Other PIIGS countries in the Post Crisis period.

We re-estimate Model 1 for all countries in our sample and add an indicator variable for European countries without the PIIGS (Non-PIIGS Europe) using the countries outside Europe as the base category. We report the results in Model 2 of Table 6 . We obtain largely the same qualitative results in Model 2 as in Model 1 with one difference: the coefficient on Other PIIGS $\times$ Crisis is positive but no longer significantly different from zero. In addition, the coefficient on Non-PIIGS Europe $\times$ Post Crisis and the sum of Post Crisis and Non-PIIGS Europe $\times$ Post Crisis are not significantly different from zero. Compared with the Pre Crisis period, the Spreads on bonds issued by private issuers and guaranteed by the Non-PIIGS Europe countries are not significantly different from the Spreads in the Pre Crisis period. 
To test the importance of default risk for the sovereigns other than Greece, we re-estimate Model 2 of Table 5 and remove the Other PIIGS and Non-PIIGS Europe indicator variables and associated interaction terms and add the Close to Junk indicator variable with Close to Junk $\times$ Crisis and Close to Junk $\times$ Post Crisis interaction terms. We report the results in Model 3 of Table 6. In Model 3 of Table 6 , note that Close to Junk $\times$ Post Crisis is positive and significant at the $1 \%$ level. The sum of Post-Crisis and Close to Junk $\times$ Post Crisis is also positive and significant at the $1 \%$ level. Compared with the Pre Crisis period, the Spread for guarantee bonds associated with a sovereign that is Close to Junk in its sovereign rating is significantly more positive. ${ }^{27}$ Similar to Greece, although with less magnitude, the guarantee bonds associated with Close to Junk sovereigns are sold with a substantially greater positive Spread in the Post Crisis period. ${ }^{28}$

As noted earlier, the Spreads in the Post Crisis period, for Greece and the Close to Junk sovereigns, strike us as puzzling. The Post Crisis period, as we define it, was still a period of considerable market uncertainty, particularly about whether Greece was going to recover after its March 2012 restructuring. During such a period, our prediction had been that the Spreads would be negative, albeit not as negative as they had been during the Crisis period. What we found, however, was that the Spreads not only turned positive, but at least for Greece by a much bigger margin than even in the Pre Crisis period. Not having answers ourselves, we turned to market insiders for explanations

${ }^{27}$ We re-defined the Close to Junk variable as equal to 1 if $\mathrm{S} \& \mathrm{P}$ rates the sovereign (other than Greece) as less than or equal to 3 rating notches above the highest level of junk status at the time of a particular guarantee bond issuance and 0 otherwise. We replaced the Close to Junk $\times$ Crisis and Close to Junk $\times$ Post Crisis interaction terms with an interaction term between the re-defined Close to Junk variable and Crisis and Post Crisis in Model 3 of Table 6. Unreported, we obtained the same qualitative results as in Model 3 of Table 6 .

${ }^{28}$ We obtained the sovereign default probability for each private bond issuance guaranteed by Greece or one of the Other PIIGS countries based on the credit default swap market price for the sovereign debt measured of these respective countries as of the issue date (CDS Default Prob). Our thanks to Julian Schumaker for sharing this data with us. See GroBe Steffen and Schumaker (2014). Note that the credit default swap market did not provide a price for every issuance-particularly for Greece during the Crisis and Post Crisis periods. We then re-estimated Model 2 of Table 6 and replaced the Greece, Other PIIGS, and Non-PIIGS Europe indicator variables and interaction terms with the CDS Default Prob variable as well as Crisis $\times$ CDS Default Prob and Post Crisis $\times$ CDS Default Prob interaction terms. Unreported, the coefficient on CDS Default Prob is positive and significant at the $5 \%$ level. The coefficients on Crisis $\times$ CDS Default Prob and Post Crisis $\times$ CDS Default Prob are both negative and significant at the $1 \%$ level. The sum of CDS Default Prob and Crisis $\times$ CDS Default Prob is negative and significant at the $1 \%$ level. The sum of CDS Default Prob and Post Crisis $\times$ CDS Default Prob is negative and significant at the $1 \%$ level. Although many of the Greek issuances were dropped from the model due to a lack of data for CDS Default Prob, for the issuances with data, the greater likelihood of a sovereign default in the Crisis and Post-Crisis periods correlates with a reduced Spread, consistent with the hypothesis that the market viewed guarantee bonds as superior to comparable sovereign bonds during the sovereign debt crisis. 
regarding the foregoing. There were three stories we heard, one more plausible than the other two.

\section{Explaining the Puzzle}

(a) Pigs to Hogs: The explanation we heard most often usually began with a reaction to our Post-Crisis graph of the Greek Spreads that went something along the following lines, "Oh, that's the Pigs to Hogs transformation". The story was that that guaranteed bonds, given that they had escaped the first restructuring completely, were going to be next on the chopping block if there was going to be another restructuring. After all, it would be unfair to impose more pain on the holders of the ordinary sovereign bonds who had just been forced to take an NPV $80 \%$ haircut. The argument has some appeal on its face and there may even be some truth to it. But the reality is that the guaranteed bonds that escaped the restructuring had relatively short maturities left on them after the Greek restructuring. In our sample, the average maturity term of Greek guaranteed bonds was only 4.6 years. Those holders who had obtained windfall profits in the March 2012 restructuring, in other words, were likely not going to be present when the next restructuring rolled around. The new holders of guaranteed bonds were, for the most part, going to be new purchasers of the bonds that had been issued in the period after March 2012 . Plus, the reality of any modern restructuring is that sovereigns will target those outstanding instruments that have the fewest legal protections and not those debt instruments that escaped the prior restructuring.

(b) The Strong New Sovereign Bonds: The second explanation is that the Greek sovereign bonds that were issued after March 2012 had strong legal protections unlike the Greek local law bonds that had been so easily haircut in the restructuring. If these legal protections were indeed so very strong, one would expect the spread between the guarantee yield and the naked sovereign yield to narrow. The problem with this explanation though is that although the legal protections in ordinary Greek sovereign bonds are indeed stronger in the post restructuring period (they are under English law now), the protections in most of the Post Crisis guaranteed bonds were either the same as those in the regular sovereign bonds (they were also under English law) or even stronger (the CACs in the guarantees were harder to restructure).

(c) Liquidity Extraction Bonds: The third explanation is the most cynical and the one that we find most plausible. Insiders describe it as the "liquidity extraction" phenomenon. It begins by asking: Why would the Greece be paying investors rates many hundreds of basis points higher on its guarantees than the market rates for ordinary Greek bonds? The answer, it was suggested to us, is related to the fact that all of the post crisis guarantee 
bonds were issued by banks; and specifically, as a way to extract liquidity from the ECB. ${ }^{29}$

According to this story, no investors bought these bonds. Or, put differently, the exorbitant yields on these bonds make sense only if the issuer and Greece itself somehow benefit and that can happen if the bonds are not being sold on the market, but instead are being used as collateral by the private issuer. In this case, the higher the interest rate, the higher the amount that can be borrowed against the collateral (since the government bonds are assumed to be zero risk instruments for purposes of the ECB's discount window).

Under this scenario, the private issuer receiving the guarantee does not actually sell the bonds to investors but instead deposits the bonds as collateral with the ECB in order to obtain more loans from the ECB. Because the guarantee bonds are both guaranteed by a sovereign and pay a high interest rate, they count as relatively high collateral, supporting a larger loan amount from the ECB. The private issuer then is able to use the loans for its own purposes or, alternatively, use the loan proceeds to purchase Greek sovereign bonds, indirectly funneling loans from the ECB to the Greek sovereign. Our initial thought had been that this liquidity extraction story would not hold up for the simple reason that the ECB surely would not permit it. However, although the ECB has indicated its strong disapproval of the practice -in theory, the ECB has a plethora of strict rules aimed at ensuring that the quality of collateral that it lends against is consistently high - recent research tells us that the ECB loosened its collateral criteria to an extraordinary extent during the 2010-2014 period. And permitting the pledging of "own use" bonds with a government guarantee to the ECB (via the local national central banks) was a part of this loosening (Eberl and Weber, 2014; Sinn, 2014). The ECB has indicated its disapproval of the practice, but its bar on banks using "own use" bonds as collateral for ECB financing only comes into place in 2015 (Spink, 2014; Thomas Jr., 2004).

The question remains though as to whether our puzzling results for Greece in the Post Crisis period are the product of this particular form of shenanigans. We believe the answer is yes, and explain why in Section 7 .

\section{The Fake Greek Yields in the Post Crisis Period}

Our initial strategy in attempting to investigate the whether the puzzling Post Crisis yields for Greek guarantee bonds were being driven by the practice of banks pledging "own use" bonds was to try and ask colleagues at the ECB. We received no responses to our questions. So, we looked elsewhere. The following

\footnotetext{
${ }^{29} \mathrm{As}$ a comparison, of the 37 Pre Crisis Greek guaranteed bonds in our full dataset, fewer than $10 \%$ (3) were issued by banks. The Appendix Table lists the 22 private issuers with Greek guaranteed bonds in the Post Crisis Period in chronological order by issue date.
} 
are the four clues we found - all of which, we believe, suggest that the Post Crisis yields on almost all of the Greek guaranteed bonds were fake. That, in turn, has implications for our pricing study that we will get to after setting forth the clues.

1. Unpacking the Post Crisis Yields: If one takes the yields for the 22 different Greek guaranteed bonds in the Post Crisis period, running from March 2012 to August 2014, and lines them up against each other, a strange picture emerges. Thirteen of these 22 yields bear an unusual degree of similarity they are all $12 \%$ plus either 1-month or 3-month Euribor. This magic number of $12 \%$ plus Euribor holds across the entire period, even though we are talking about bonds for multiple banks (four), with different levels of financial strength and across a period where the perceived strength of the Greek economy varied considerably.

The high yields in the Post Crisis period are particularly puzzling given that while Greece's risk of default diminished relative to the Crisis period, it had not, as of August 2014 the end of our Post Crisis period, returned to the risk levels in the Pre Crisis period. We obtained sovereign default probabilities for each private guarantee bond issuance guaranteed by Greece based on the credit default swap market price for the sovereign debt measured of these respective countries as of the issue date. ${ }^{30}$ Due to disruptions in the credit default swap market during the crisis, we did not obtain a price for every issuance during the Crisis and Post Crisis periods. For the data we did obtain, the mean default probability for Greece (averaged over each private guarantee issuance) during the Pre Crisis period was $1.9 \%$. In comparison the mean default probability for Greece during the Crisis period was $20 \%$ and during the Post Crisis period was $10.3 \%$. While the default probability for Greece diminished in the Post Crisis period, it did not come back down to Pre Crisis levels.

2. The Dealogic Gap: Dealogic is the database that probably has the most extensive set of information on issuances of government bonds. Industry insiders primarily use Dealogic because it produces rankings of the various participants in the financial markets in terms of the volumes of deals that they have done. These participants - banks, law firms and so on-therefore have strong incentives to supply Dealogic with information on their deals. Now, as with any one of the major databases (Thomson One Banker, Perfect Information and Bloomberg are the other three), there are gaps in Dealogic's reporting in that deals are missed. But, in the case of the Post-Crisis Greek guarantee bonds, there are none that show up on Dealogic. When we called the Dealogic representatives handling our subscription, they explained that the gap in their reporting was probably because of what they thought was an unusual aspect of these deals - they didn't have a real investment banking firm listed. Instead, the issuing bank itself was listed as the investment bank. That

\footnotetext{
${ }^{30}$ See supra note 27 , for the source of these probabilities.
} 
is strange because unless the issuer in question is a AAA sovereign like the US, Germany or Japan, it typically needs an investment bank and its clients so as to be able to sell its bonds. So, who was buying these Greek guarantee bonds with their $12 \%$ plus Euribor yields?

3. The Missing Buyers: We next tried to find the buyers of these bonds with their extremely lucrative yields. We concede that we are not what one might call market insiders. But our extensive research on the sovereign debt markets over the past decade has meant that we have a number of contacts in the sovereign debt industry, including with some of the hedge funds that invest in sovereign bonds, journalists who follow the industry and who have examined this specific issue, officials at various government debt offices and bankers in Greece. We asked all of our contacts and no one knew of any private investors who had purchased these bonds (although some jokingly said that they would like to buy some, if we could find out how that could be done).

4. The Piraeus Bank Bond: Our final clue came from an issue by the Piraeus Bank, a Greek bank that had been one of those institutions issuing with the benefit of a Greek sovereign guarantee in the Post Crisis period. In March 2014, it was able to issue a naked, non-guaranteed 3-year bond at a rate of $5.125 \%$ (Thompson and Wigglesworth, 2014). The Greek sovereign, for its part, also returned to the market around this time, issuing a five-year bond in early April 2014 at 4.95\% (Alderman and Thomas, 2014). Now, let us look at the yield on the Greek guaranteed bond issued by Piraeus Bank just about a month prior to its regular bond issue. On a one-year bond, it was $12.183 \%$ (12\% plus 3-month Euribor). ${ }^{31}$ How is it that a bond, with a significantly shorter maturity (one year), that is backed by both the assets of the state and the bank, has a yield that is more than twice the yield on either the bank's naked bond (three year) or the sovereign's naked bond (five year) $?^{32}$ Indeed, the whole point of the sovereign giving the bank a guarantee is to lower the yield at which the bank is able to borrow; here, we see that it raises it. As the old Indian saying goes, something is black in the lentils.

Putting the clues together, our conclusion is that the yields on most of the Post Crisis Greek guarantee bonds cannot be trusted. ${ }^{33}$ Specifically, if use the combination of whether the bond was (a) omitted by Dealogic and (b) had one of the strange $12 \%$ plus Euribor interest rates, we are left with no Greek guarantee bonds issued in the Post Crisis period. The question is what this implies for the inquiry at the heart of the paper; whether the market was pricing in the

\footnotetext{
${ }^{31}$ This information is from the offering circular extracted from the Perfect Information database.

${ }^{32}$ One sees a similarly strange pattern in the bonds issued by Alpha Bank in July 2014. Its own bonds have a much lower yield than its bonds with a Greek government guarantee.

${ }^{33} \mathrm{We}$ are not the only ones to suspect the yields on these bonds to be fake. The Greek Finance Minister (some months prior to becoming the Minister) has said so as well. See Varoufakis (2014).
} 
legal advantages attached to guarantee bonds in the pre crisis period? At first cut, the implications are heartening. Once we toss out the Post Crisis yields, we have what looks to be a nice clean story of how the markets during good times and even not-so-good times, tend to attach greater value to the liquidity benefits of naked sovereign bonds than to the legal advantages of the less liquid guarantee bonds. But, at some point, the likelihood of default becomes high enough that the legal advantages become important. And that importance continues to increase as one gets closer and closer to the default point.

\section{Conclusion}

Much though we would like to end on the high note of having demonstrated how the market did price in the legal advantages of the Greek guaranteed bonds, our own analysis showing that some of the Post Crisis yields were suspicious leaves us open to the question of how many other yields in our dataset are also fake. As of this writing, we have not been able to determine that. But we are optimistic that our dataset is large enough that even if there are a few more yields that are problematic, the bottom line results will hold, if not improve.

And what about those fake yields? If our suspicions about those Post Crisis guarantee bonds are right, and if the banks issuing them and depositing them as collateral with the ECB are as weak as is indicated by the need to engage in such shenanigans, this boils down to a big additional Post Crisis loan by the ECB to the Greek state (one commentator estimates at amounting to Euro $41 \mathrm{bn}$ ) (Varoufakis, 2014). The reason for that is that if the banks are unable to repay their loans from the ECB, then the ECB will be forced to activate the collateral (the bonds from the same banks that are out of funds). That in turn will mean that the guarantees get triggered and the bonds effectively become sovereign bonds. And Greece's already exorbitant sovereign debt stock gets even bigger.

\section{A. Appendix}

\begin{tabular}{lc}
\hline Private Issuer & Issue Date \\
\hline EFG Bank & $5 / 8 / 12$ \\
Piraeus Bank SA & $6 / 4 / 12$ \\
Eurobank Ergasias & $8 / 8 / 12$ \\
Eurobank Ergasias & $8 / 14 / 12$ \\
Eurobank Ergasias & $4 / 26 / 13$ \\
\hline
\end{tabular}

Table A1: Private issuers with Greek guaranteed bonds. 


\begin{tabular}{lc}
\hline Private Issuer & Issue Date \\
\hline Alpha Bank & $4 / 30 / 13$ \\
Piraeus Bank SA & $5 / 1 / 13$ \\
National Bank of Greece SA & $5 / 8 / 13$ \\
Alpha Bank & $5 / 20 / 13$ \\
Eurobank Ergasias & $5 / 20 / 13$ \\
Alpha Bank & $6 / 19 / 13$ \\
National Bank of Greece SA & $6 / 20 / 13$ \\
Eurobank Ergasias & $6 / 25 / 13$ \\
Piraeus Bank SA & $12 / 6 / 13$ \\
National Bank of Greece SA & $12 / 11 / 13$ \\
Alpha Bank & $12 / 16 / 13$ \\
Eurobank Ergasias & $12 / 18 / 13$ \\
Piraeus Bank SA & $2 / 6 / 14$ \\
Alpha Bank & $5 / 15 / 14$ \\
Alpha Bank & $6 / 5 / 14$ \\
Alpha Bank & $7 / 21 / 14$ \\
Alpha Bank & $8 / 29 / 14$ \\
\hline
\end{tabular}

Table A1: Continued.

Description: The table lists the 22 private issuers with Greek guaranteed bonds in the Post Crisis Period in chronological order by issue date.

\section{References}

Aglietta, M. 2011. "The Twin Sovereign and Banking Crisis in the Euro Area". Cepii. URL: http://www.cepii.com/BLOG/bi/post.asp?IDcommunique=36. Alderman, L. and L. Thomas. 2014. "Taking a Risk, Investors Snap Up OnceShunned Greek Debt". New York Times. April 10, 2014.

Alfaro, L., N. Mauer, and F. Ahmed. 2010. "Gunboats and Vultures: Market Reaction to the "Enforcement" of Sovereign Debt". URL: http://www.econ. ucla.edu/workshops/papers / History / Maurer, \%5C\%20Gunboats\%5C\% 20and\%5C\%20Vultures, \%5C\%20version\%5C\%205.2.pdf.

Bardozetti, A. and D. Dottori. 2013. "Collective Action Clauses: How do They Weigh on Sovereigns". Banca D'Italia Working Paper: 897.

Becker, T., A. Richards, and Y. Thaicharoen. 2003. "Bond Restructuring and Moral Hazard: Are Collective Action Clauses Costly?" Journal of International Economics. 61: 127.

Black, J. 2012. "ECB Said to Swap Greek Bonds for New Bonds to Avoid Losses". Bloomberg. February 17, 2012. URL: http://www.bloomberg.com/ news /2012-02-16/ecb-said-to-swap-greek-bonds-for-new-debt-to-avoidloss-from-restructuring.html. 
Bouras, S. and A. Granitsas. 2012. "Greece Faces Bond Swap Holdouts". Wall Street Journal. (April 2).

Bradley, M., J. Cox, and M. Gulati. 2010. "The Market Reaction to Legal Shocks and Their Antidotes". The Journal of Legal Studies. 39: 289.

Bradley, M. and M. Gulati. 2014. "Collective Action Clauses for the Eurozone: An Empirical Analysis". Review of Finance. 18: 2045.

Buchheit, L. C., A. Gelpern, M. Gulati, U. Panizza, B. Weder di Mauro, and J. Zettelmeyer. 2013. "Revisiting Sovereign Bankruptcy". Brookings. URL: http://www.brookings.edu//media/research/files/reports/2013/10/ sovereign-bankruptcy/ciepr_2013_revisitingsovereignbankruptcyreport.pdf.

Buchheit, L. C. and M. Gulati. 2013. "The Gathering Storm: Contingent Liabilities in Sovereign Debt Restructuring". URL: http://papers.ssrn.com/ sol3 $/$ papers.cfm?abstract_id $=2292669$.

Chamon, M., C. Trebesch, and J. Schumaker. 2014. "Foreign Law Bonds: Can They Reduce Sovereign Borrowing Costs?" Working Paper.

Chaturvedi, N. 2014. "Greek Bank Issues at 5.1\%, Really". Wall Street Journal. March 18, 2014.

Choi, S. J., M. Gulati, and E. A. Posner. 2011. "Pricing Terms in Sovereign Debt Contracts: A Greek Case Study". Capital Markets Law Journal. 6: 163.

Clare, A. and N. Schmidlin. 2014. "The Impact of Foreign Governing Law on European Bond Yields". URL: http://papers.ssrn.com/sol3/papers.cfm? abstract_id $=2406477$.

Dutch Bank Hands Greece Set Back. 2012. CBS. April 18, 2014. URL: http: //www.cbsnews.com/news/dutch-bank-hands-greece-debt-setback/.

Eberl, J. and C. Weber. 2014. "ECB Collateral Criteria: A Narrative Database 2001-2013". Ifo Working Paper \# 174.

Eichengreen, B. and A. Mody. 2004. "Do Collective Action Clauses Raise Borrowing Costs". The Economic Journal. 114: 247.

Ejsing, J., M. Grothe, and O. Grothe. 2012. "Liquidity and Credit Risk Premia in Government Bond Yields". ECB Working Paper \# 1440.

Gelpern, A. and M. Gulati. 2013. "The Wonder-Clause". Journal of Comparative Economics. 41: 367. (describing the debates over CACs).

GroBe Steffen, C. and J. Schumaker. 2014. "Debt Restructuring in the Euro Area: How Can Sovereign Debt be Restructured More Effectively". DIW Economic Bulletin.

Gugiatti, M. and A. Richards. 2003. "Do Collective Action Clauses Influence Bond Yields? New Evidence from Emerging Markets". Reserve Bank of Australia Working Paper. URL: http://www.rba.gov.au/publications/rdp/ 2003/pdf/rdp2003-02.pdf.

Häseler, S. 2009. "Collective Action Clauses in International Sovereign Bond Contracts - Whence the Opposition?" Journal of Economic Surveys. 23: 882. 
Kroszner, R. 1998 draft. "Is it Better to Forgive than to Receive: Repudiation of the Gold-Indexation Clause in Long-Term Debt During the Depression". URL: http://faculty.chicagobooth.edu/finance/papers/repudiation11.pdf.

Langstaff, F. 2004. "The Flight to Liquidity Premium in Treasury Bond Prices". The Journal of Business. 77: 511.

Levy, A. and A. Zaghini. 2010. "The Pricing of Government-Guaranteed Bonds". Banca D'Italia, Eurosistema Working Papers \# 753.

Merler, S. and J. Pisani-Ferry. 2012. "Hazardous Tango: Sovereign-Bank Interdependence and Financial Stability in the Euro Area". Financial Stability Review. 16: 201-210.

Moore, E. and K. Hope. 2014. "Greece Launches Sale of Five-Year Bond". Financial Times. April 8, 2014.

Salmon, F. 2014. "Why Puerto Rico's Bonds are Moving to New York". Reuters. March 3, 2014. URL: http://blogs.reuters.com/felix-salmon/2014/03/03/ why-puerto-ricos-bonds-are-moving-to-new-york/.

Schuster, P. and M. Uhrig-Homburg. 2013. "The Term Structure of Bond Market Liquidity Conditional on the Economic Environment: An Analysis of Government Guaranteed Bonds". URL: http://papers.ssrn.com/sol3/ papers.cfm?abstract_id $=2033170$.

Sinn, H.-W. 2014. The Euro Trap: Of Bursting Bubbles, Budgets and Beliefs. Oxford University Press.

Spink, C. 2014. "Greek Banks Confront Liquidity Issues". International Financial Review. June 7, 2014.

Thomas Jr., L. 2004. "A Note of Caution in Greek Banks' Seeming Recovery". New York Times. May 7, 2004.

Thompson, C. and R. Wigglesworth. 2014. "Robust Demand for Piraeus Bank Bond Offer". Financial Times. March 19, 2014.

Varoufakis, Y. 2014. "How the Greek Banks Secured an Additional, Hidden Euro 41 Billion Bailout From the European Taxpayers". URL: http://www. thepressproject.net/article/61683/How- the-Greek-Banks-Secured-anAdditional-Hidden-41-billion-Bailout-from-European-taxpayers.

Weidemaier, M. W. C. 2014. "Sovereign Immunity and Sovereign Debt". University of Illinois Law Review. 67.

Zettelmeyer, J. and M. Gulati. 2012. "Making a Voluntary Greek Debt Exchange Work". Capital Markets Law Journal. 7: 169.

Zettelmeyer, J., C. Trebesch, and M. Gulati. 2013. "The Greek Debt Restructuring: An Autopsy". Economic Policy. 28: 75. 